Consumer-led development of novel sea buckthorn-based beverages

Geertsen, Julie; Allesen-Holm, Bodil Helene; Byrne, Derek Victor; Giacalone, Davide

Publication date:

2014

Document version

Publisher's PDF, also known as Version of record

Citation for published version (APA):

Geertsen, J., Allesen-Holm, B. H., Byrne, D. V., \& Giacalone, D. (2014). Consumer-led development of novel sea buckthorn-based beverages. Poster session presented at EuroSense 2014: A Sense of Life, Copenhagen, Denmark. 


\section{Poster Programme}

\begin{tabular}{|c|c|c|c|c|c|}
\hline $\begin{array}{c}\text { Poster } \\
\text { Session }\end{array}$ & Presentation Date & Presentation Time & Poster Numbers & Pin Up & Take Down \\
\hline $\mathbf{1}$ & $\begin{array}{c}\text { Monday 8 } \\
\text { September }\end{array}$ & $13: 00-14: 00$ & $\begin{array}{c}\text { P001-P185 } \\
\text { And all oral posters }\end{array}$ & $\begin{array}{c}\text { Sunday } 7 \\
\text { September from } \\
13: 00\end{array}$ & $\begin{array}{c}\text { Monday } 8 \\
\text { September by } \\
16: 00\end{array}$ \\
\hline $\mathbf{2}$ & $\begin{array}{c}\text { Tuesday 9 } \\
\text { September }\end{array}$ & $14: 00-15: 00$ & $\begin{array}{c}\text { P186-P367 } \\
\text { Any late posters }\end{array}$ & $\begin{array}{c}\text { Tuesday } 9 \\
\text { September from } \\
08: 30\end{array}$ & $\begin{array}{c}\text { Wednesday } 10 \\
\text { September by } \\
13: 00\end{array}$ \\
\hline
\end{tabular}

\section{Poster Session 1}

\begin{tabular}{|c|c|}
\hline $\begin{array}{l}\text { Poster } \\
\text { Number }\end{array}$ & Poster Title \\
\hline [P001] & $\begin{array}{l}\text { Elderly people's preference for meal appearance and composition } \\
\text { M.D. Aaslyng*, M.A. Tørngren, L. Meinert, Danish Meat Research Institute, Denmark }\end{array}$ \\
\hline [P002] & $\begin{array}{l}\text { Sensorial analysis of the usage of soy sauce as a strategy to lower sodium intake } \\
\text { M.E.M. Pinto-e-Silva, L. Aburad*, A.P.G. Geraldo, R.R.B. Silva, Universidade de São Paulo, Brazil }\end{array}$ \\
\hline [P003] & 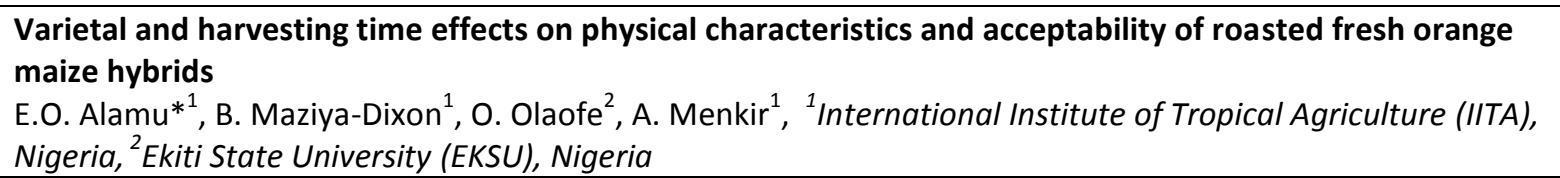 \\
\hline [P004] & $\begin{array}{l}\text { The effect of different Ca preparates on the sensory quality of functional beverages with dietary fibers } \\
\text { A. Liutkevicius, G. Alencikiene*, V. Speiciene, A. Miezeliene, Kaunas University of Technology, Lithuania }\end{array}$ \\
\hline [P005] & $\begin{array}{l}\text { Implementing sensory panel methods in sensory focus groups to achieve more actionable } \\
\text { recommendations for product development } \\
\text { T. Alex* }{ }^{1} \text {, O. Gautreau }{ }^{1},{ }^{1} S A M \text { Sensory and Marketing International GmbH, Switzerland, }{ }^{2} \text { SAM Sensory and } \\
\text { Marketing International GmbH, France }\end{array}$ \\
\hline [P006] & $\begin{array}{l}\text { One new food a day: Frequent one-time exposures to unfamiliar foods improve preadolescent children's } \\
\text { willingness to try new foods } \\
\text { V.L. Almli }{ }^{1}{ }^{,} \text {A. Nilsen }{ }^{2,1} \text {, I. Berget }{ }^{1} \text {, N. Lien }{ }^{2} \text {, M. Hersleth }{ }^{1},{ }^{1} \text { Nofima, Norway, }{ }^{2} \text { Institute of Basic Medical } \\
\text { Sciences, Faculty of Medicine, University of Oslo, Norway }\end{array}$ \\
\hline [P007] & $\begin{array}{l}\text { SensMixed - an R-package for mixed effects modelling for sensory and consumer data } \\
\text { I.S. Amorim } *^{1,2}, \text { A. Kuznetsova }{ }^{1} \text {, R.R. Lima }{ }^{2} \text {, R.H.B. Christensen }{ }^{1}, \text { P.B. Brockhoff }{ }^{1},{ }^{1} \text { Technical University of } \\
\text { Denmark, Denmark, }{ }^{2} \text { Universidade Federal de Lavras, Brazil }\end{array}$ \\
\hline [P008] & $\begin{array}{l}\text { Measures of sensory satisfaction and overall satisfaction lead to a more detailed understanding of } \\
\text { consumer's affective product perception than measures of liking alone } \\
\text { B.V. Andersen }{ }^{1}, \text { G. Hyldig }{ }^{1} \text {, I. Viemose }{ }^{2} \text {, S. Jensen }{ }^{3} \text {, J. Laugesen }{ }^{2}, \text { W.L.P. Bredie }{ }^{2},{ }^{1} \text { Technical University of } \\
\text { Denmark, Denmark, }{ }^{2} \text { University of Copenhagen, Denmark, }{ }^{3} \text { Aarhus University, Denmark }\end{array}$ \\
\hline [P009] & $\begin{array}{l}\text { Size matters! Does serving size affect the result when conducting acceptance tests? } \\
\text { B.V. Andersen }{ }^{1}, \mathrm{~S} \text {. Jensen }{ }^{2}, \mathrm{G} \text {. Hyldig }{ }^{1},{ }^{1} \text { Technical University of Denmark, Denmark, }{ }^{2} \text { Aarhus University, } \\
\text { Denmark }\end{array}$ \\
\hline [P010] & $\begin{array}{l}\text { Evaluating size of differences between products } \\
\text { P. Arents }{ }^{1}, \text { M. Foucras }{ }^{1}, \text { C. Perrin }{ }^{2},{ }^{1} \text { Givaudan, The Netherlands, }{ }^{2} \text { Givaudan, Switzerland }\end{array}$ \\
\hline [P011] & $\begin{array}{l}\text { Do wine consumers use the terms included in the mouth-feel wheel when thinking about astringency? } \\
\text { L. Vidal, A. Giménez, G. Ares*, Universidad de la República, Uruguay }\end{array}$ \\
\hline [P012] & $\begin{array}{l}\text { Does a product-focused food choice questionnaire predict consumer responses to a choice conjoint task? } \\
\text { L. Vidal, A. Giménez, G. Ares*, Universidad de la República, Uruguay }\end{array}$ \\
\hline [P013] & $\begin{array}{l}\text { Does personality influence snacking choices among adolescents? } \\
\text { F. Mawad, M. Benedetti, A. Giménez, G. Ares*, Universidad de la República, Uruguay }\end{array}$ \\
\hline [P014] & $\begin{array}{l}\text { Evaluation of data aggregation in polarized sensory positioning } \\
\text { L. Antúnez }{ }^{1}, \mathrm{~A} \text {. Salvador }{ }^{2} \text {, L. de Saldamando }{ }^{1} \text {, P. Varela }{ }^{3}, \mathrm{~A} \text {. Giménez }{ }^{1}, \mathrm{G} \text {. Ares }{ }^{* 1},{ }^{1} \text { Universidad de la República, } \\
\text { Uruguay, }{ }^{2} \text { Instituto de Agroquímica y Tecnología de Alimentos, Spain, }{ }^{3} \text { Nofima, Norway }\end{array}$ \\
\hline [P015] & Paper withdrawn \\
\hline [P016] & $\begin{array}{l}\text { An eye tracking analysis of consumer attention to a weight-loss beverage TV commercial } \\
\text { M. Asakawa*, M. Okano, Bunkyo University, Japan }\end{array}$ \\
\hline [P017] & $\begin{array}{l}\text { High intensity sweeteners in espresso coffee: Quantitative descriptive analysis and time-intensity analysis } \\
\text { B. Azevedo*, H. Bolini, F. Schmidt, Unicamp, Brazil }\end{array}$ \\
\hline [P018] & $\begin{array}{l}\text { Investigation of facial coding as a means of evaluating NPD concepts } \\
\text { P. Bailey*, A. Franklin, C. Barnagaud, MMR Research Worldwide, UK }\end{array}$ \\
\hline
\end{tabular}


[P019] Italian taralli as typical bakery products: Sensory and physical measurements to assess their quality S. Barbieri*, F. Balestra, P. Rocculi, T. Gallina Toschi, A. Bendini, Bologna University, Italy

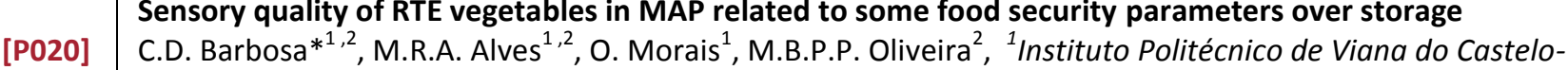
ESTG, Portugal, ${ }^{2}$ REQUIMTE-Universidade do Porto, Portugal

[P021] Acceptation of sensory labelling by consumers

R. Barrena*, T. García, Universidad Pública de Navarra, Spain

Comparing free choice profile and flash profile for the sensory characterization of Brazilian cherry nectars

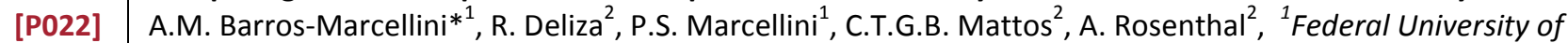
Rio de Janeiro, Brazil, ${ }^{2}$ Embrapa Food Technology, Brazil

[P023] Age and gender effect on reported liking and intake of coarse vegetables: A Danish cross-sectional survey T.K. Beck*, S. Jensen, U. Kidmose, Aarhus University, Denmark

[P024] Age and gender effect on reported liking of basic tastes among adult Danish consumers

T.K. Beck*, S. Jensen, U. Kidmose, Aarhus University, Denmark

[P025] Biotechnology on food production: A quali-quantitative approach T.G. Ribeiro, J.H. Behrens*, University of Campinas, Brazil

[P026] A comparison of methods to include different variance/error structures of sensory and consumer data F. Belmonte*, R.H.B. Christensen, P.B. Brockhoff, Technical University of Denmark, Denmark

[P027] Impact of number of samples on consumer acceptance, intensity and ideal ratings

R. Boekholt*, P.H. Punter, K. Nuijten, OP\&P Product Research, The Netherlands

[P028] Can you use consumer focus groups to develop and test package design? R.P. Hamlin ${ }^{1}$, M. Gin ${ }^{1}$, J. Bogue* ${ }^{2},{ }^{1}$ University of Otago, New Zealand, ${ }^{2}$ University College Cork, Ireland "Harmony" of extra virgin olive oils (EVOOs) / insights from the long-term project "International Olive Oil

[P029] Award - Zurich" M. Popp, A. Bongartz*, ZHAW - Zurich University of Applied Sciences, Switzerland "SENPAN" - Swiss panel of elderly people / insights into nutritional and sensory changes in elderly people

[P030] J. Rudorf, S. Clauss, J. Kinner, A. Bongartz*, C. Brombach, ZHAW - Zurich University of Applied Sciences, Switzerland

[P031] Insights into sensory changes in elderly people / "SENPAN" - Swiss panel of elderly people J. Rudorf, J. Kinner, A. Bongartz*, ZHAW - Zurich University of Applied Sciences, Switzerland

[P032] The impact of age on perception / Liking of sucrose and citric acid enriched apple juices in young and elderly people

M. Bruckner, J. Kinner, A. Bongartz*, ZHAW - Zurich University of Applied Sciences, Switzerland Salty and umami congruent odor improve palatability of salt-reduced foods K. Bonkohara*, M. Fuji, S. Noma, N. Igura, M. Shimoda, Kyushu University, Japan

[P034] Consumers' preferences and taste perception toward raw and heated cheeses C. Bord*, A. Miyatani, D. Guerinon, A. Lebecque, VetAgro Sup, France Interest of complementary methods for understanding consumer choice. Example of French bread nutrionally improved

[P035]

C. Bord* ${ }^{1}$, A. Miyatani ${ }^{1}$, D. Guerinon ${ }^{1}$, A. Chatillon ${ }^{2}$, A. Vera ${ }^{3}$, A. Lebecque ${ }^{1},{ }^{1}$ VetAgro Sup, France, ${ }^{2}$ LIMAGRAIN, France, ${ }^{3}$ Phil $X N$, France

The role of involvement and familiarity on overall acceptability of meat products

[P036] M. Borgogno ${ }^{* 1}$, A.V. Cardello ${ }^{2}$, S. Favotto ${ }^{1}$, E. Piasentier ${ }^{1},{ }^{1}$ University of Udin, Italy, ${ }^{2}$ U.S. Army Natick Soldier RD\&E Center, USA

[P037] R-packages for sensometrics by DTU Compute

P.B. Brockhoff*, A. Kuznetsova, R.H.B. Christensen, Danish Technical University, Denmark

[P038] Development of a predictive model for consumer appreciation of different meat products

K. Broucke, G. Van Royen, T. Rysman*, ILVO, Belgium

[P039] Branding moderates the impact of effort on food intake

T.A. Brunner, Bern University of Applied Sciences, Switzerland

[P040] Factors affecting check all that apply (CATA) responses

D.T. Buck $*^{1}$, A. Hasted ${ }^{2}$, Y. Taylor ${ }^{1},{ }^{1}$ product perceptions Itd., UK, ${ }^{2}$ QI Statistics, UK

Consumers perception from three regions of Brazil concerning lipsticks differences

[P041] J.T. Bueno* ${ }^{1}$, M.C. Marcolini ${ }^{1}$, D.A. Maciel ${ }^{1}$, S. Féderle ${ }^{1}$, V.V. Silva ${ }^{1}$, C. Neto $^{1}$, M.T. Paccola ${ }^{1}$, M. Lorencini $^{1}$, V.M. Di Mambro ${ }^{1},{ }^{1}$ Cencoderma Instituição de Pesquisa, Brazil, ${ }^{2}$ Sensenova Desenvolvimento e Pesquisa Sensorial, Brazil

Sensory evaluation of shine in nail polishes using similar methodology to Munsell Color Test ${ }^{\circledR}$

[P042] J.T. Bueno*, M.C. Marcolini, S. Federle, D.S.C. Budie, M. Lorencini, V.M. Di Mambro, Cencoderma Instituição de Pesquisa, Brazil 
[P043]

Comparison of sensory characteristics of meat from red deer, fallow deer and Aberdeen Angus and

Holstein cattle

D. Bureš*, L. Bartoň, R. Kotrba, Institute of Animal Science, Czech Republic

[P044]

Hedonic napping ${ }^{\circledR}$ : A new way of combining descriptive and hedonic data for numerous products

H. Cadiou*, L. Defeyter, F. Abiven, Reperes, France

Identification of sensory attributes driving overall perceived quality of smoothies

[P045] E. Campo* ${ }^{1}$, M. Lozano ${ }^{1}$, E. Arias ${ }^{1}$, S. Remón ${ }^{1},{ }^{1}$ University of Zaragoza, Spain, ${ }^{2}$ Aula Dei Scientific and Technological Park, Spain

[P046] Relationship between aromatic profile and acceptability of sourdough gluten-free breads

E. Campo*, L. Del Arco, A.I. Negueruela, R. Oria, A. Ferrer, University of Zaragoza, Spain

Emotion questionnaires: The effect of the number of emotions on consumer responses

[P047] A.V. Cardello* ${ }^{1}$, M. Bogogno ${ }^{2}$, C. Craig $^{1}$, L.L. Lesher ${ }^{1},{ }^{1}$ U.S. Army Natick RD\&E Center, USA, ${ }^{2}$ University of Udine, Italy

Linking sensory characteristics of apples by the age of the respondent and the colour of the breed

[P048] L. Casetti* ${ }^{1}$, C. Brugger ${ }^{2}$, T. Brunner $^{1},{ }^{1}$ Bern University of Applied Sciences, Switzerland, ${ }^{2}$ Agroscope, Switzerland

The interplay of qualitative and quantitative messages in shaping consumers' preferences for food safety

[P049] under various certifying regimes: The case of Lebanon

A. Chalak*, M. Abiad, American University of Beirut, Lebanon

[P050] Exploring tablets for undergraduate school work

Y. Chung, D. Chambers*, L. Lo, Kansas State University, USA

[P051] $\begin{aligned} & \text { Influence of orthonasal stimulation on liking and perceived flavour intensity } \\ & \text { M-H. Chapalay*, P. Bürgisser, P. Hulliger, L. Stegmüller, T. Brunner, Bern University of Applied Sciences, }\end{aligned}$ Switzerland

Dynamism of flavour perception phenomena: Complementarity of sensory and instrumental temporal methods

[P052]

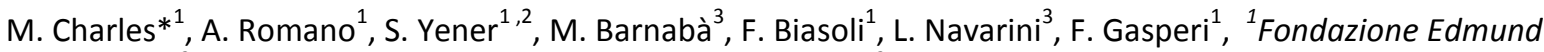
Mach, Italy, ${ }^{2}$ Leopold-Franzens Universität Innsbruck, Austria, ${ }^{3}$ Illycaffè S.p.a., Italy

Influence of different climatic conditions on the sensory quality of apples

[P053] M.L. Corollaro ${ }^{1,2}$, M. Charles* ${ }^{1}$, L. Manfrini ${ }^{2}$, I. Endrizzi ${ }^{1}$, E. Aprea ${ }^{1}$, A. Zanella ${ }^{3}$, L. Corelli Grapadelli ${ }^{2}$,

F. Gasperi ${ }^{1},{ }^{1}$ Fondazione Edmund Mach, Italy, ${ }^{2}$ Alma Mater Studiorum - University of Bologna, Italy, ${ }^{3}$ Research Centre for Agriculture and Forestry Laimburg, Italy

[P054] Sensory comparison of organically and conventionally produced scab-resistant apples

M. Charles*, M.L. Corollaro, J. Zambanini, E. Aprea, I. Endrizzi, F. Gasperi, Fondazione Edmund Mach, Italy

Instrumental colour evaluation and visual consumer study of commercial beverages made with fruit juice and milk

[P055]

R. Fernández-Vázquez ${ }^{1}$, C.M. Stinco ${ }^{1}$, F.J. Heredia ${ }^{1}$, C. Chaya $*^{*}{ }^{2}$ I.M. Vicario ${ }^{1},{ }^{1}$ University of Seville, Spain, ${ }^{2}$ Technical University of Madrid, Spain

Sensory characterization and consumer acceptance of la mancha trujillo melons fertilized with different

[P056] dosages of pomace compost

E. Sánchez-Palomo ${ }^{1}$, M.A. Ferrer-Valverde ${ }^{1}$, C. Chaya* ${ }^{2}$, M.A. González-Viñas ${ }^{1},{ }^{1}$ University of Castilla-La Mancha, Spain, ${ }^{2}$ Technical University of Madrid, Spain

Drivers of linking for the lotus root Bugak (Korean traditional fried dishes)

[P057] J.E. Yang ${ }^{1}$, J.H. Lee ${ }^{1}$, Y.O. Song ${ }^{2}$, E. Choe ${ }^{3}$, L. Chung $*^{1},{ }^{1} K_{\text {Kyung Hee University, Republic of Korea, }}{ }^{2}$ Pusan National University, Republic of Korea, ${ }^{3}$ Inha University, Republic of Korea

Conjoint analysis between sensorial characteristics, nutritional properties and price ranges of breakfast

[P058] cereals

C.T. Colantonio* ${ }^{1}$, L.E. Lemarcis ${ }^{1}$, L.M. Levi ${ }^{1}$, F.N. Fernandes Carvalho ${ }^{1}$, M.L. Marand ${ }^{1}$, A.M. Appriou ${ }^{1}$, P.L.A.M. Pensé-Lheritier ${ }^{1}$, T.B. Thuillier ${ }^{2},{ }^{1}$ Ecole de Biologie Inductrielle, France, ${ }^{2}$ ABT Informatique, France Linking consumer emotions and liking responses with sensory characteristics to drive growth of the

[P059] nutrition bar category in the United States and Europe

C.C. Conley*, L.K. Hendrix, K.A. Hogan, DuPont Nutrition \& Health, USA

[P060] Are consumers concerning about food colors? D.P.R. Azeredo ${ }^{1}$, L.S.M. Moura ${ }^{1}$, A. Cruz ${ }^{* 1}$, A. Sabaa-Srur ${ }^{2}$, E.A. Esmerino ${ }^{2},{ }^{1}$ IFRJ, Brazil, ${ }^{2}$ UFRRJ, Brazil

[P061] Contribution of mindfulness-based theory to product testing: A pilot study C. Cuny* ${ }^{1}$, L. Strub ${ }^{2},{ }^{1}$ Grenoble Ecole de Management, France, ${ }^{2}$ Grenoble Ecole de Management, France SounBe, an innovative sound project tool involving sensory analysis: New possible applications in food 
Interindividual differences in liking during repeated exposure to drink stimuli

J.R. Dalenberg ${ }^{1,2}$, L. Nanetti ${ }^{1,2}$, R.J. Renken ${ }^{1,2}$, R.A. de Wijk ${ }^{1,3}$, G.J. ter Horst ${ }^{1,2},{ }^{1}$ Top Institute Food and

[P063] Nutrition, The Netherlands, ${ }^{2}$ University Medical Center Groningen, The Netherlands, ${ }^{3}$ Wageningen University and Research Centre, The Netherlands

Facial expressions and autonomous nervous system responses elicited by tasting different juices

[P064] L. Danner* ${ }^{1,2}$, S. Haindl ${ }^{3}$, K. Duerrschmid ${ }^{1},{ }^{1}$ University of Natural Resources and Life Science (BOKU), Austria, ${ }^{2}$ University of Applied Sciences Wiener Neustadt, Austria, ${ }^{3}$ University of Vienna, Austria

Visual attention and choice behavior in multi-alternative choice situations

[P065] L. Danner ${ }^{1,2}$, N. deAntoni ${ }^{1}$, T. Poscher ${ }^{1}$, K. Duerrschmid ${ }^{2},{ }^{1}$ University of Applied Sciences Wiener Neustadt, Austria, ${ }^{2}$ University of Natural Resources and Life Sciences (BOKU), Austria

A possible behavioural approach to obesity: Links between visual cues in serving food and food

[P066] $\begin{aligned} & \text { consumption } \\ & \text { L. De Carli* }{ }^{1} \text {, D. Dal Palù }{ }^{2} \text {, V. Bicchiega }{ }^{3},{ }^{1} \text { Università di Torino, Italy, }{ }^{2} \text { Politecnico di Torino, Italy, }{ }^{3} \text { Istituto }\end{aligned}$ Auxologico Italiano IRCCS, Italy

\section{Distinct single-bite eating phases demonstrated by electromyography}

[P067] J. Derks ${ }^{1,2}$, R.A. de Wijk ${ }^{* 1,3}$, C. de Graaf ${ }^{1,2}$, M. Stieger ${ }^{1,2}$, J.H.F. Bult ${ }^{1,4},{ }^{1}$ TI Food and Nutrition, The Netherlands, ${ }^{2}$ Wageningen University, The Netherlands, ${ }^{3}$ WUR, The Netherlands, ${ }^{4}$ NIZO Food Research, The Netherlands

[P068] Tetrad test as a viable tool for decision tests in the food industry

M. Deck*, E. Heinloth, L. Bell, K. Jahnke, Kraft Foods Inc., R\&D Munich, Germany

[P069] Effective communication of novelty: The case of ripened cheese

[P069] K.C. Deegan*, I. Palmujoki, J. Isotalo, H. Tuorila, University of Helsinki, Finland

[P070] CATA on emotions and focus groups

C. Dehlholm*, G. Hansen, Danish Technological Institute, Denmark

The history of descriptive methods - A chronological overview

[P071] C. Dehlholm* ${ }^{1}$, W.L.P. Bredie ${ }^{2},{ }^{1}$ Danish Technological Institute, Denmark, ${ }^{2}$ University of Copenhagen, Denmark

Brazilian consumers and the conceptualization of wellbeing in the context of food consumption

[P072] D.C.R. Oliveira ${ }^{1}$, R. Deliza*2, F.R. Rodrigues ${ }^{3}$, R.C. Souza ${ }^{1}$, G. Ares ${ }^{4},{ }^{1}$ IQ/Federal University of Rio de Janeiro, Brazil, ${ }^{2}$ Embrapa Food Technology, Brazil, ${ }^{3}$ DTA/Federal Rural University of Rio de Janeiro, Brazil, ${ }^{4}$ Universidad de La República, Uruguay

\section{Consumer attitude and preference towards frozen burgers}

[P073] M.M. Viana ${ }^{1}$, V.L.S. Silva ${ }^{1}$, R. Deliza* ${ }^{2}$, C.S. Favaro-Trindade ${ }^{1}$, M.A. Trindade ${ }^{1},{ }^{1}$ University of São Paulo, Brazil, ${ }^{2}$ Embrapa Food Technology, Brazil

Consumer perception of salt reduction in Minas Frescal cheese

[P074] C. Barros ${ }^{1}$, A. Rosenthal ${ }^{2}$, E.H. Walter ${ }^{2}$, R. Deliza*2, ${ }^{1}$ Federal Rural University of Rio de Janeiro, Brazil, ${ }^{2}$ Embrapa Food Technology, Brazil

The trade-off between nutritional benefits and price when evaluating a non-familiar product

[P075] K.R. Romano ${ }^{1}$, A. Rosenthal ${ }^{2}$, R. Deliza*2, ${ }^{1}$ Federal Rural University of Rio de Janeiro, Brazil, ${ }^{2}$ Embrapa Food Technology, Brazil

Tilapia cooked by different methods: Sensory characterization using Flash profile

[P076] J.C. Andrade ${ }^{1,2}$, W. Rocha ${ }^{1}$, R.C. Souza ${ }^{2}$, R. Deliza* ${ }^{3}$, J.R. Gonçalves ${ }^{1},{ }^{1}$ Institute of Food Technology, Brazil, ${ }^{2}$ Federal University of Rio de Janeiro, Brazil, ${ }^{3}$ Embrapa Food Technology, Brazil

Drivers of consumption of oral nutritional supplements in frail community and care home dwelling elderly: A means-end chain approach

[P077] L.C. den Uijl ${ }^{1}$, S. Kremer ${ }^{1}$, G. Jager ${ }^{2}$, A.J. van der Stelt ${ }^{3}$, C. de Graaf ${ }^{2}$, J.B. Lawlor ${ }^{3},{ }^{1}$ Food \& Biobased Research Wageningen UR, The Netherlands, ${ }^{2}$ Wageningen UR, The Netherlands, ${ }^{3}$ Danone Nutricia Research, The Netherlands

A new approach to analyse open-ended questions: Application on the concept of minerality in wine

[P078] P. Deneulin* ${ }^{1,4}$, Y. Le Fur ${ }^{2}$, L. Gautier ${ }^{3}$, F. Bavaud ${ }^{4},{ }^{1}$ Changins - University for Viticulture and Oenology, Switzerland, ${ }^{2}$ AgroSup Dijon, France, ${ }^{3}$ Université de Bourgogne, France, ${ }^{4}$ University of Lausanne, Switzerland

[P079] Investigation of emotional expressions elicited by wine odour A. Rivé, P. Deneulin*, Changins - University for Viticulture and Oenology, Switzerland

[P080] Development of a food-related identification test for olfactory assessment M.Y. Denzer*, N. Thuerauf, J. Kornhuber, A. Buettner, FAU, Germany

[P081] Improving our knowledge on the role of TDS (total dissolved solids) on the flavour of water V. García, M. Paraira, R. Devesa*, Aigües de Barcelona, Spain 
[P082] D.S.C. Budie, S. Federle, J.T. Bueno, M.C. Marcolini, V.M. Di Mambro*, Cencoderma Instituição de Pesquisa, Brazil

The influence of packing in purchase and repurchase decision of cosmetics products

[P083] M.C. Marcolini, J.T. Bueno, D.S.C. Budie, S. Federle, M. Lorencini, V.M. Di Mambro*, Cencoderma Instituição de Pesquisa, Brazil

[P084] The emperor's new nose

G.B. Dijksterhuis ${ }^{11}{ }^{2}$, D. de Grave ${ }^{1},{ }^{1}$ Unilever $R \& D$, The Netherlands, ${ }^{2}$ University of Copenhagen, Denmark Do culture, food type, place of consumption and the sensory properties of food influence the emotional response of consumers?

[P085] G. Donadini ${ }^{1}$, M.D. Fumi ${ }^{1}$, E. Kordialik-Bogacka ${ }^{2},{ }^{1}$ Università Cattolica del Sacro Cuore, Italy, ${ }^{2}$ Lodz University of Technology, Poland

[P086] school meals?

G. Donadini*, M.D. Fumi, Università Cattolica del Sacro Cuore, Italy

[P087] First position effect on the emotional response of consumers: A case study in chocolate and beers R. Dorado*, A. Picard, C. Pérez-Hugalde, C. Chaya, Technical University of Madrid, Spain

[P088] An inspiring vision of implicit measures to understand consumers' relationship with products L. Dreyfuss*, H. Nicod, Biofortis Sensory \& Consumer, France Social and cultural influences in designing cross-cultural consumer research - Case studies in China and

[P089] Brazil L. Dreyfuss*, H. Nicod, A. Eschevins, Biofortis Sensory \& Consumer, France

[P090] The Affective Misattribution Procedure (AMP) as a preference measurement L. Dreyfuss*, H. Nicod, J. Mallard, Biofortis Sensory \& Consumer, France

[P091] Variability in sensory trained panels' performances

L. Dreyfuss*, H. Nicod, Biofortis Sensory \& Consumer, France

[P092] Napping ${ }^{\circledR}$ and free sorting, a reproducibility study using savoury samples

C. Dubreuil ${ }^{* 1}$, L. Hewson ${ }^{2}$, J. Hort ${ }^{2},{ }^{1}$ Mars Petcare, UK, ${ }^{2}$ University of Nottingham, UK

Memory description and liking of coloured cake

[P093] S. Jantathai ${ }^{1,2}$, A. Mukprasirt ${ }^{3}, \mathrm{~K}$. Duerrschmid* ${ }^{1},{ }^{1}$ University of Natural Resources and Life Sciences Vienna, Austria, ${ }^{2}$ Mahasarakham University, Thailand, ${ }^{3}$ King Mongkut's University of Technology, Thailand

[P094] Addition of vinegar to "cabeça de xara" made from Alentejano pig meat increases shelf life M. Laranjo, M.E. Potes, M. Elias*, Universidade de Évora, Portugal

[P095] Influence of objective and subjective knowledge on the acceptability of different quality virgin olive oils A.C. Ellis*, L. Raggio, C. Feller, A. Gámbaro, Universidad de la República, Uruguay

[P096] Arginine improves sensory acceptance of probiotic low sodium cheese T. Felicio ${ }^{1}$, A. Cruz ${ }^{1}$, E. Esmerino $*^{2}$, H. Bolini ${ }^{2},{ }^{1}$ IFRJ, Brazil, ${ }^{2}$ UNICAMP, Brazil

Acceptability of probiotic Petit Suisse with jabuticaba skin extract

[P097] E.P.R. Pereira, R.N. Cavalcanti, A.G. Cruz, E.A. Esmerino*, M.A.A. Meireles, H.M.A. Bolini, J.A.F. Faria, UNICAMP, Brazil

[P098] Consumer acceptance of probiotic cream cheese with reduced sodium chloride content E.M.V. Alves, E.A. Esmerino*, A.G. Cruz, H.M.A. Bolini, J.A.F. Faria, UNICAMP, Brazil

Descriptive sensory profile of powder chocolate beverage, sweetened with sucrose and different [P099] sweeteners

J.A. Paixão, E.A. Esmerino*, H.M.A. Bolini, University of Campinas, Brazil

Determination of drivers of liking on sodium reduced sausages with mechanically deboned poultry meat added of derivatives of garlic

[P100] C.N. Horita, E.A. Esmerino*, A.G. Cruz, F.M. Hayakawa, V.C. Messias, H.M.A. Bolini, M.A.R. Pollonio, UNICAMP, Brazil

[P101] beverage containing chia oil (Salvia hispanica) J.B. Rodrigues, E.A. Esmerino*, H.M.A. Bolini, UNICAMP, Brazil

Determination of sensory attributes that influence acceptability of probiotic cottage cheeses by penalty [P102] analysis methodology A.L.T. Jesus, E.A. Esmerino*, A.G. Cruz, H.M.A. Bolini, J.A.F. Faria, UNICAMP, Brazil 
Evaluation of acceptability of peach nectars sweetened with sucrose and different sweeteners

A.C.M.L. Da Silva, E.A. Esmerino*, H.M.A. Bolini, UNICAMP, Brazil

[P106] powder chocolate beverage

J.A. Paixão, E.A. Esmerino*, H.M.A. Bolini, University of Campinas, Brazil

[P107] Just-about-right test: An easy way to

E.M.V. Alves, E.A. Esmerino*, A.G. Cruz, H.M.A. Bolini, J.A.F. Faria, UNICAMP, Brazil

Sensory evaluation of acceptability of low sodium sausages with mechanically deboned chicken meat added of garlic compounds

[P108]

C.N. Horita, E.A. Esmerino*, A.G. Cruz, F.M. Hayakawa, V.C. Messias, H.M.A. Bolini, M.A.R. Pollonio, UNICAMP, Brazil

[P109]

Time-intensity profile of peach nectars sweetened with sucrose and different sweeteners

A.C.M.L. Da Silva, E.A. Esmerino*, H.M.A. Bolini, UNICAMP, Brazil

Development of references for sensory evaluation of lamb meat

[P110] I. Etaio*, L. Bravo-Lamas, G. Zudaire, E. Unzueta, X. Belaunzaran, F.J. Pérez-Elortondo, N. Aldai, University of the Basque Country (UPV/EHU), Spain

Is check-all-that-apply (CATA) appropriate to differentiate among meat products by consumers and to

[P111] explain the liking?

M. Ojeda, I. Etaio*, M.P.F. Gil, M. Albisu, J. Salmerón, F.J. Pérez-Elortondo, UPV/EHU, Spain,

Panel training and qualification for sensory characterization of lamb meat

[P112] I. Etaio*, L. Bravo-Lamas, G. Zudaire, E. Unzueta, X. Belaunzaran, F.J. Pérez-Elortondo, N. Aldai, University of the Basque Country; UPV/EHU, Spain

Differences between female and male hedonic perceptions on fragrances

[P113] S. Federle*, J.T. Bueno, M.C. Marcolini, D.S.C. Budie, M. Lorencini, V.M. Di Mambro, Cencoderma Instituição de Pesquisa, Brazil

[P114] S. Federle*, D.S.C. Budie, J.T. Bueno, M.C. Marcolini, M. Lorencini, V.M. Di Mambro, Cencoderma Instituição de Pesquisa, Brazil

Olfactive performance evaluation of diffusers fragrances and sticks

[P115] S. Federle*, D.S.C. Budie, J.T. Bueno, M.C. Marcolini, M. Lorencini, V.M. Di Mambro, Cencoderma Instituição de Pesquisa, Brazil

[P116] Paper withdrawn

Developmentt of light cereal bar with banana and bifidobamalis animalis subsp. lactis BB12

[P117] C.V. Caravieri, T.M. Gama, V.V. Aquino, I. Racowski, J.P. Ferraz*, Faculdade de Tecnologia Termomecanica, Brazil

[P118] Sweetness equivalent of different sweeteners in probiotic vanilla ice cream

J.P. Ferraz*, H.M. Bolini, Universidade Estadual de Campinas, Brazil

[P119] Time-intensity analysis in prebiotic ice cream

J.P. Ferraz*, H.M.A. Bolini, Universidade Estadual de Campinas, Brazil

Predicting the sensory characteristics of French grape brandies on the basis of their volatile profiles

[P120] G. Fiches ${ }^{* 1,2}$, I. Déléris ${ }^{2,3}$, A. Saint-Eve ${ }^{2,3}$, P. Brunerie ${ }^{1}$, I. Souchon ${ }^{2,3},{ }^{1}$ Pernod Ricard Research Center, France, ${ }^{2}$ INRA UMR782 GMPA, France, ${ }^{3}$ AgroParisTech UMR782 GMPA, France

[P121] S. Fiszman ${ }^{1}$, P. Morell ${ }^{2}, \mathrm{P}$. Varela ${ }^{1}, \mathrm{I}$. Hernando ${ }^{2},{ }^{1}$ Instituto de Agroquimica y Tecnologia de Alimentos (IATA CSIC), Spain, ${ }^{2}$ Universistat Politecnica de Valencia, Spain

Picture scales for evaluating relative expected satiety (R.E.S.)

[P122] S. Fiszman*1 ${ }^{1}$, P. Morell ${ }^{1}$, C. Ramírez ${ }^{2}$, A. Tárerega ${ }^{1},{ }^{1}$ Instituto de Agroquimica y Tecnologia de Alimentos (IATA CSIC), Spain, ${ }^{2}$ Universidad de las Américas Puebla, Mexico

What is satiating? Consumer perceptions of satiating foods

[P123] S. Fiszman $*^{1}$, P. Varela ${ }^{1}$, P. Díaz ${ }^{2}$, M.B. Linares ${ }^{2}$, M.D. Garrido ${ }^{2},{ }^{1}$ Instituto de Agroquímica y Tecnología de Alimentos (IATA-CSIC), Spain, ${ }^{2}$ University of Murcia, Spain

Effect of different concentrations of starch on gel beads shaping and firmness characteristics

[P124] D. Duarte ${ }^{1}$, P. Morais ${ }^{2}$, R. Pinheiro ${ }^{1,3}$, M.H. Gomes ${ }^{2}$, C. Barbosa ${ }^{1,4}$, A. Araujo ${ }^{1,3}$, S. Fonseca* ${ }^{1}$, M.R. Alves ${ }^{1,4}$, M. Vaz-Velho ${ }^{1},{ }^{1}$ Instituto Politécnico de Viana do Castelo, Portugal, ${ }^{2}$ Centro de Inovação e Tecnologia AgroAlimentar, Portugal, ${ }^{3}$ University of Minho, Portugal, ${ }^{4}$ Laboratório Associado para a Química Verde, Portugal 
Influence of biopreservation and modified atmosphere packaging on the high appealing sensory attributes of sliced smoked pork products

[P125] R. Pinto ${ }^{1}$, S. Jacome ${ }^{1}$, S.C. Fonseca* ${ }^{1,2}$, R. Pinheiro ${ }^{1}$, M.R. Alves ${ }^{1,2}$, R. Palencia ${ }^{3}$, J. Silva ${ }^{3}$, P. Teixeira ${ }^{3}$, M. Vaz-Velho ${ }^{1},{ }^{1}$ Instituto Politécnico de Viana do Castelo, Portugal, ${ }^{2}$ REQUIMTE, Portugal, ${ }^{3}$ Universidade Católica Portuguesa, Portugal

Kinetics of consumption, an innovative tool to measure cat food palatability

J. Roguès, L. Le Paih, C. Forges*, C. Niceron, Diana Pet Food, France

[P127] Australian lamb - a sensory and consumer lead strategy

D.C. Frank*, R. Krishnamurthy, P. Watkins, U. Piyasiri, R.D. Warner, CSIRO, Australia

Sensory characterization of dry soup formulated with whole red rice extruded flour

[P128] M. Alcantara ${ }^{1}$, C.Y. Takeiti ${ }^{2}$, D.D.G.C. Freitas* ${ }^{2}$, S.C. Freitas ${ }^{2},{ }^{1}$ Federal Rural University of Rio de Janeiro, Brazil, ${ }^{2}$ Embrapa Food Technology, Brazil

Using red rice flour and raspberry's pomace to create a cereal-based powder drink

[P129] R.C. Souza ${ }^{1}$, D.D.G.C. Freitas ${ }^{2}{ }^{2}$, C.Y. Takeiti ${ }^{2}$, S.C. Freitas ${ }^{2}$, R.G. Borguini ${ }^{2},{ }^{1}$ Universidade Federal do Rio de Janeiro, Brazil, ${ }^{2}$ Embrapa Food Technology, Brazil

[P130] Influence of packaging in consumers' perception of cosmetic creams

A. Gámbaro*, A. Roascio, L. Boinbaser, E. Parente, Universidad de la República, Uruguay

Job sorting technique to assess the brand image of cream liqueurs

[P131] A. Gámbaro* ${ }^{1}$, C. Ivankovich ${ }^{2}$, A. Roascio ${ }^{1}$, M. Miraballes ${ }^{1}$, M. Amarillo ${ }^{1}$, A. Pavlisko ${ }^{1}$, A. Araya ${ }^{2},{ }^{1}$ Universidad $^{-}$ de la República, Uruguay, ${ }^{2}$ Universidad de Costa Rica, Costa Rica

Effect of glass shape on behavioral and subjective responses in a real context of drink consumption

[P132] D. Cliceri ${ }^{1}$, E. Petit ${ }^{1}$, C. Garrel ${ }^{*}{ }^{2}$, A. Giboreau ${ }^{1},{ }^{1}$ Institut Paul Bocuse, France, ${ }^{2}$ Research Center Pernod Richard, France

[P133] C. Garrel* ${ }^{1}$, E. Petit ${ }^{2}$, L. Saulais ${ }^{2}$, D. Viala ${ }^{1}$, A. Giboreau ${ }^{2},{ }^{1}$ Pernod Ricard Research Center, France, ${ }^{2}$ Center for Food and Hospitality, Institut Paul Bocuse, France

[P134] How to exploit JAR scales and CATA best, considering the interactions between product characteristics O. Gautreau*, M. Kern, SAM Sensory and Marketing International GmbH, France

Consumer-led development of novel sea-buckthorn based beverages

[P135] J. Geertsen*1, D.V. Byrne ${ }^{2}$, B.H. Allesen-Holm ${ }^{1}$, D. Giacalone ${ }^{1},{ }^{1}$ University of Copenhagen, Denmark, ${ }^{2}$ University of Aarhus, Denmark

Comparison of the computation method of panellist's discrimination ability, applied in MAM-CAP, to other approaches

[P136] A. Gere ${ }^{* 1}$, M. Ladányi ${ }^{1}$, K. Dürrschmid ${ }^{2}$, L. Sipos ${ }^{1},{ }^{1}$ Corvinus University of Budapest, Hungary, ${ }^{2}$ University of Natural Resources and Life Sciences, Austria

Pair-wise correlation method: Impact of JAR attributes on overall liking

[P137] A. Gere* ${ }^{1}$, L. Sipos ${ }^{1}$, K. Dürrschmid ${ }^{2}$, K. Héberger ${ }^{3},{ }^{1}$ Corvinus University of Budapest, Hungary, ${ }^{2}$ University of Natural Resources and Life Sciences, Austria, ${ }^{3}$ Hungarian Academy of Sciences, Hungary

The application of partial least squares regression and Jack-knife resampling for verification of product

[P138] differences and important variables in consumer-based CATA profiles

A. Rinnan, D. Giacalone*, M.B. Frøst, University of Copenhagen, Denmark

The influence of product familiarity on situational appropriateness

[P139] D. Giacalone ${ }^{* 1}$, S.R. Jaeger ${ }^{2},{ }^{1}$ University of Copenhagen, Denmark, ${ }^{2}$ The New Zealand Institute for Plant \& Food Research, New Zealand

Using a dynamic method based on video recording to describe drinking behavior in a real context:

[P140] Identification of three types of drinkers

D. Cliceri ${ }^{1}$, E. Petit ${ }^{1}$, C. Garrel ${ }^{2}$, A. Giboreau $*^{1},{ }^{1}$ The Center for Food and Hospitality Research, Institut Paul Bocuse, France, ${ }^{2}$ Research Center Pernod Richard, France

[P141] What could food designers learn from chefs to innovate and please consumers?

A. Giboreau, The Center for Food and Hospitality Research, Institut Paul Bocuse, France

Exploring the use of survival analysis as a tool to predict freshness in minimally processed lettuce

[P142] A. Gimenez*, L. Vidal, L. Antunez, S. Barrios, M. Irazoqui, P. Lema, G. Ares, Universidad de la Republica, Uruguay

Comparison of rapid sensory characterization methodologies for the development of functional yogurts

[P143] R.S. Cadena ${ }^{1}$, D. Caimi ${ }^{1}$, I. Jaunarena ${ }^{1}$, I. Lorenzo ${ }^{1}$, L. Vidal ${ }^{1}$, G. Ares ${ }^{1}$, R. Deliza ${ }^{2}$, A. Giménez ${ }^{*}{ }^{1},{ }^{1}$ Universidad de la República, Uruguay, ${ }^{2}$ Embrapa Food Technology, Brazil 
Understanding new product categories: Mixing quantitative test with consumer ethnographies

C. Gomez-Corona* ${ }^{1}$, H.B. Escalona-Buendia ${ }^{1}$, M. Garcia ${ }^{2}$, S. Chollet ${ }^{3}$, D. Valentin ${ }^{4},{ }^{1}$ Universidad Autonoma

[P145]

Metropolitana, Mexico, ${ }^{2}$ Phenoma, Mexico, ${ }^{3}$ Groupe ISA Institut Charles Viollette, France, ${ }^{4}$ Centre des Sciences du Goût et de l'Alimentation, France

[P146] Impact of food consistency in dynamic perception of simple model systems

A.H.M. Goupil de Bouille ${ }^{* 1}$, L. Laguna ${ }^{1},{ }^{1}$ Leatherhead Food Research, UK, ${ }^{2}$ Leeds University, UK

[P147] Taking the consumer pulse on food labelling

N.J. Patterson, E. Gubish, A.H.M. Goupil de Bouille*, Leatherhead Food Research, UK

[P148] Taking the consumer pulse on sustainability

N.J. Patterson, E. Gubish, A.H.M. Goupil de Bouille*, Leatherhead Food Research, UK

[P149] Temporal dominance of sensation as new tool for sensory shelf life in food products

A.H.M. Goupil de Bouille*1, L. Laguna ${ }^{1},{ }^{1}$ Leatherhead Food Research, UK, ${ }^{2}$ Leeds University, UK

Cross-cultural study on descriptive evaluation of table margarines in Hungary and in the United Kingdom

[P150] A. Györey ${ }^{1}$, A. Gere ${ }^{1}$, D. Jackson ${ }^{2}$, Z. Kókai ${ }^{1}$, A. Goupil de Bouillé $*^{2},{ }^{1}$ Corvinus University of Budapest, Hungary, ${ }^{2}$ Leatherhead Food Research, UK

[P151] Do claims really make a diff

S. Peleteiro Costa, A. Willey, J.S. Arden, A. Goupil de Bouillé*, Leatherhead Food Research, UK

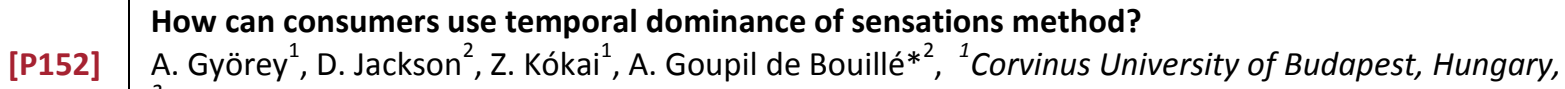
${ }^{2}$ Leatherhead Food Research, UK

The impact of personal relevance and perceived product benefits on consumers' purchase intentions of

[P153] hedonic and utilitarian food products with nutritional claims

N. Loebnitz, K. Grunert*, Aarhus University, Denmark

[P154] Dry-cured ham culture and factors determining their purchase intention

M.D. Guàrdia ${ }^{1}$, A. Claret ${ }^{1}$, E. Magallón ${ }^{2}$, J. Noguera ${ }^{1}$, L. Guerrero* ${ }^{1},{ }^{1}$ IRTA, Spain, ${ }^{2}$ INGAFOOD, Spain

[P155] Sensory characterization of different varieties of peaches and nectarines (Prunus persica)

L. Guerrero*, A. Claret, T. Bianchi, M. Hortós, I. Díaz, I. Eduardo, M. Gratacós-Cubarsí, IRTA, Spain

Textural properties of different varieties of melon (Cucumis melo L.)

[P156] T. Bianchi, L. Guerrero*, M. Gratacós-Cubarsí, A. Claret, J.A. García-Regueiro, J. Argyris, J. Garcia-Mas, M. Hortós, IRTA, Spain

[P157] How the sweet taste changes when we see what we drink

G. Guido*, L. Piper, M. Pichierri, I. Prete, A. Mileti, E. De Franchis, University of Salento, Italy

Emotional responses to taste and package and their impact on food choice

[P158] S. Gutjar*1,2, C. De Graaf ${ }^{1,2}$, R.A. De Wijk ${ }^{1,3}$, G. Jager ${ }^{2},{ }^{1}$ Top Institute Food and Nutrition, The Netherlands,

${ }^{2}$ Wageningen University, The Netherlands, ${ }^{3}$ Wageningen UR Food \& Biobased Research, The Netherlands

Development of e-Sensory - use of modern electronic methods for conducting "in home" sensory assessments

T.D.J. Hagan*, L.H. Majury, L.J. Farmer, Agrifood and Bioscience Institute, UK

[P160] Impact of variety and ripening on eating quality of peaches and nectarines

T.D.J. Hagan*, L. Majury, L.J. Farmer, A.W. Gordan, Agri-Food and Bioscience Institute, UK

[P161] Food labelled with health claims - estimation of health value and hedonic rating among young consumers J. Hampshire*, L. Page, University of Applied Sciences Fulda, Germany

[P162] Study on shelf life of emulsified sauces and dressings being opened before storing

I. Pape ${ }^{1}$, K. Huber ${ }^{2}$, D. Hanrieder $*^{1},{ }^{1}$ Hochschule Anhalt, Germany, ${ }^{2}$ Byodo Naturkost GmbH, Germany

[P163] Attenuated oral fatty acid chemoreception is associated with excess energy intake

[P163] R.S.J. Keast, K.M. Azzopardi, L.P. Newman, R.Y. Haryono*, Deakin University, Australia

[P164] Consumer perception of meal satisfaction

P. Haugaard*, L. Lähteenmäki, Aarhus University, Denmark

[P165] Using sensory science to fight HIV: Optimization of a semisolid vaginal drug delivery system J.E. Hayes*, T. Zaveri, R.J. Primrose, G.R. Ziegler, Penn State, USA

Temporal development of facial expressions and autonomic nervous system responses to food odors

[P166] W. He ${ }^{*^{1,2}}, \mathrm{~S}$. Boesveldt ${ }^{2}$, C. de Graaf ${ }^{2}$, R.A. de Wijk ${ }^{1},{ }^{1}$ Wageningen University \& Research Centre, The Netherlands, ${ }^{2}$ Wageningen University, The Netherlands

Preferences of ready meal packages among senior consumers in Finland and in the Netherlands E. Rusko ${ }^{1}$, A. Maaskant ${ }^{2}$, S. Kremer ${ }^{2}$, R. Ristiluoma ${ }^{3}$, A. Arvola ${ }^{1}$, R-L. Heiniö ${ }^{* 1},{ }^{1}$ VTT Technical Research Centre of Finland, Finland, ${ }^{2}$ Wageningen UR Food and Biobased Research, The Netherlands, ${ }^{3}$ Taloustutkimus Oy, Finland 
Product information effects on consumers' evaluation of commercial and experimental salmon cakes

[P168] K. Pennanen ${ }^{1}$, R-L. Heiniö ${ }^{1}$, K. Sveinsdottir ${ }^{2}$, E. Martinsdottir ${ }^{1},{ }^{1}$ VTT Technical Research Centre of Finland, Finland, ${ }^{2}$ Matís ohf., Iceland

Giving products "identity" - Importance of a "Sensory DNA" for successful brands

[P169] S. Glassl ${ }^{1}$, R. Möslein ${ }^{2}$, A. Scharf ${ }^{1,2}$, S. Henneberg* ${ }^{2},{ }^{1}$ University of Applied Science Nordhausen, Germany, ${ }^{2}$ isi $\mathrm{GmbH}$, Germany

Strength and determinants of the First Position Effect (1PoE)

[P170] M. Brömlage, H-P. Volkmer, A. Scharf, M. Strack, S. Henneberg*, isi Marketing Research \& Consulting, Sensory Analysis, Germany

[P171] Flavour pairings; A consumer study of beer and cheese

L. Hewson ${ }^{* 1}$, S. Woodford ${ }^{1}$, A. Barlow ${ }^{2}$, D. Cook ${ }^{1},{ }^{1}$ University of Nottingham, UK, ${ }^{2}$ AllBeer, UK

[P172] Taste perception: The effect of menstrual cycle phase on taste sensitivity

L. Hewson*, H. Bunday, Q. Yang, J. Hort, University of Nottingham, UK

Global red wine flavour preferences: A cross-cultural study

[P173] R. Ristic ${ }^{1}$, A. Hoek* ${ }^{2}$, T.E. Johnson ${ }^{1}$, S.E.P. Bastian ${ }^{1},{ }^{1}$ The University of Adelaide, Australia, ${ }^{2}$ University of Canberra, Australia

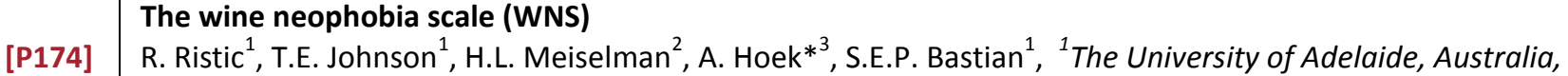
${ }^{2}$ Herb Meiselman Training and Consulting Services, USA, ${ }^{3}$ University of Canberra, Australia

Going green or not worth a red cent? An Australian online qualitative study into healthy and sustainable food behaviours to inform policy makers

[P175] A.C. Hoek ${ }^{* 1}$, S.W. James ${ }^{2}$, S. Friel ${ }^{2}$, M.A. Lawrence ${ }^{3}$, D. Pearson ${ }^{1},{ }^{1}$ University of Canberra, Australia, ${ }^{2}$ Australian National University, Australia, ${ }^{3}$ Deakin University, Australia Aroma analysis of apple cider using HS-SPME-GC/MS, GC-O and QDA

[P176] M. Holm ${ }^{*}{ }^{1}$, R. Kuldjärv ${ }^{1},{ }^{1}$ Competence Centre of Food and Fermentation Technologies (CCFFT), Estonia, ${ }^{2}$ Tallinn University of Technology, Estonia

Neurobiology of age-related changes associated with liking of basic tastes

[P177] H.R. Hoogeveen* ${ }^{1,2}$, J.R. Dalenberg ${ }^{1,2}$, G.J. Ter Horst ${ }^{1,2}$, M.M. Lorist ${ }^{2,3},{ }^{1}$ Top Institute Food and Nutrition, Wageningen, The Netherlands, ${ }^{2}$ University Medical Center Groningen, Groningen, The Netherlands, ${ }^{3}$ University of Groningen, The Netherlands

Measuring emotion: The long and short of it

[P178] C. Eaton ${ }^{1}$, C. Chaya ${ }^{2}$, K.A. Smart ${ }^{3}$, J. Hort* ${ }^{*},{ }^{1}$ The University of Nottingham, UK, ${ }^{2}$ Technical University of Madrid, Spain, ${ }^{3}$ SABMiller plc, UK

[P179] Multisensory flow experience creation through augmented-reality interactive technology T.L. Huang*, S.L. Liao, Yuan Ze University, Taiwan

Streaming sensory experience through media connecting: The impact of TV program on augmented-reality [P180] sensory IT usage behaviour T.L. Huang*, S.L. Liao, College of Management, Yuan Ze University, Taiwan

Taste interactions in trinary mixtures of basic tastes - results from the Danish sensory inter-laboratory

[P181] $\begin{aligned} & \text { study } \\ & \text { G. Hyldig*1 }{ }^{1} \text {, S. Møller }{ }^{2}, \text { K. Lorensen }{ }^{3}, \text { U. Kidmose }{ }^{4},{ }^{1} \text { The Technical University of Denmark, Denmark, }{ }^{2} \text { DuPont }\end{aligned}$ Nutrition Biosciences, Denmark, ${ }^{3}$ Arla Foods, Denmark, ${ }^{4}$ Aarhus University, Denmark

[P182] Evaluation of the influence of cosmetic ritual on women night C. Innocent* ${ }^{1}$, F. Duforez ${ }^{2}$, A. Dubois ${ }^{2}$, S. Rivoire ${ }^{1},{ }^{1}$ Laboratoires M\&L, France, ${ }^{2}$ European Sleep Center, France Chemosensory reactivity and food neophobia in preschool children: Impact of smell, but not of taste

[P183] S. Monnery-Patris ${ }^{1}$, S. Wagner ${ }^{1}$, N. Rigal $^{2}$, C. Schwartz ${ }^{1}$, C. Chabanet $^{1}$, S. Issanchou* ${ }^{1}$, S. Nicklaus ${ }^{1},{ }^{1}$ INRA France, ${ }^{2}$ Paris-Ouest University, France

Does a weight loss goal influence consumer attitudes towards foods and beverages with appetite control claims?

[P184] D.C. Hunter, D.I. Hedderley, V.S. Jones, S.R. Jaeger*, The New Zealand Institute for Plant \& Food Research Ltd, New Zealand

Hedonic perceptions of buckwheat bread: Comparison between regular and not regular consumers of special types of bread

[P185] D. Jambrec*, M. Pestoric, M. Sakac, A. Mandic, A. Mišan, N. Nedeljkovic, P. Jovanov, Institute of Food Technology, Serbia 


\section{Poster Session 2}

Poster

Number

[P186] B. Šaric, D. Jambrec*, N. Nedeljkovic, A. Mišan, M. Pestoric, J. Kos, A. Mandic, Institute of Food Technology, Serbia

The impact of food reformulation and product labelling on consumer acceptance - a taste-conjoint

[P187] approach

A.M. Janssen ${ }^{* 1}$, L. van Tiel ${ }^{2}$, S. Boesvelt ${ }^{2}$, E.P.J. Boer ${ }^{1}$, S. Kremer ${ }^{1},{ }^{1}$ Wageningen University and Research, The Netherlands, ${ }^{2}$ Wageningen University, The Netherlands

Beet-chokeberry juice as method against hypertension - sensory evaluation of bioactive product

[P188] A. Jedrusek-Golinska*, K. Szymandera-Buszka, K. Waszkowiak, K. Goscinna, J. Czapski, Poznan University of Life Sciences, Poland

[P189] 作

A.L.T. Jesus*, E.A. Esmerino, A.G. Cruz, H.M.A. Bolini, J.A.F. Faria, UNICAMP, Brazil

Association between parental attitudes towards advertised food and drink products with their children's taste preferences and their dietary behaviour

H. Jilani*1 ${ }^{1}$, H. Pohlabeln ${ }^{1}$, K. Buchecker ${ }^{2}$, S. De Henauw ${ }^{3}$, Y. Kourides ${ }^{4}$, L. Lissner ${ }^{5}$, D. Molnar ${ }^{6}$, L.A. Moreno ${ }^{7}$,

[P190] L. Reisch ${ }^{8}$, P. Russo ${ }^{9},{ }^{1}$ Leibniz Institute for Prevention Research and Epidemiology - BIPS, Germany, ${ }^{2}$ TTZ, Germany, ${ }^{3}$ Ghent University, Belgium, ${ }^{4}$ Research and Education Institute of Child Health, Cyprus, ${ }^{5}$ University of Gothenburg, Sweden, ${ }^{6}$ University of Pécs, Hungary, ${ }^{7}$ University of Zaragoza, Spain, ${ }^{8}$ Copenhagen Business School, Denmark, ${ }^{9}$ National Research Council, Italy

Measuring fungiform papillae density on the tip of the tongue to complement measuring sensory taste

[P191] function in children

H. Jilani ${ }^{1}$, K. Buchecker ${ }^{2}$, P. Russo ${ }^{3}$, W. Ahrens ${ }^{1},{ }^{1}$ Leibniz Institute for Prevention Research and Epidemiology BIPS, Germany, ${ }^{2}$ TTZ, Germany, ${ }^{3}$ National Research Council, Italy

Effect of ingredients on rheological and mechanical properties of chickpea gels related to texture

[P192] properties perceived by a trained panel

M.J. Jiménez*, W. Canet, R. Fuentes, M.D. Alvarez, Institute of Food Science, Spain

Application of modified PrefQuest questionnaire to assay recalled liking for salt, sweet, fat, and umami for Japanese consumers

[P193] Y. Nakano* ${ }^{1}$, C. Kasamatsu ${ }^{2}$, M. Nonaka ${ }^{2}$, P. Schlich ${ }^{3}$, M. Kasai ${ }^{1},{ }^{1}$ Ochanomizu University, Japan, ${ }^{2}$ Ajinomoto Co.,INC., Japan, ${ }^{3}$ INRA-CSGA, France

[P194] The impact of food pairing in hedonic product evaluation

M. Kern*, T. Alex, SAM Sensory and Marketing International GmbH, Germany

\begin{tabular}{l|l} 
[P195] & $\begin{array}{l}\text { Influence of location and information on consumers' acceptance of curly kale ice cream } \\
\text { U. Kidmose }{ }^{1}, \text { L.H. Mielby }\end{array}{ }^{1}, \mathrm{M}$. Pedersen ${ }^{2}, \mathrm{~S}$. Jensen ${ }^{1},{ }^{1}$ Aarhus University, Denmark, ${ }^{2}$ VIA University College
\end{tabular} Aarhus, Denmark

Consumer Survey for developing health-caring spreadable sauce with seafood

[P196] Y.K. Kim*1, J-Y. Shin ${ }^{1}$, M-A. Bang ${ }^{2},{ }^{1}$ Kyungpook National University, Republic of Korea, ${ }^{2}$ Jeonnam Biofood Technology Center, Republic of Korea

[P197] Priming effect and inattentional blindness: An experimental study on decision making H.K. Kindermann, University of Applied Sciences Upper Austria, Austria

Application of the WellSense ${ }^{\mathrm{TM}}$ questionnaire to measure consumer wellness response to different food recipes

S.C. King*, M. Gillette, K. Vetter, G. Patterson, McCormick \& Co., Inc, USA

Consumers perception of emotion questions in a central location test situation

S.R. Jaeger ${ }^{1}$, S.C. King ${ }^{2},{ }^{1}$ Plant and Food Research, New Zealand, ${ }^{2}$ McCormick \& Co., Inc., USA

[P200] Sensory characteristics and emotional response of consumers to different flavouring substances

E. Kostyra*, T. Soluch, Warsaw University of Life Sciences, Poland

[P201] Sensory interaction of the stevia-sweetener in flavoured model matrices and its temporal aspects E. Kostyra*, K. Różyc, G. Wasiak-Zys, A. Piotrowska, Warsaw University of Life Sciences, Poland The acceptance of protein enriched drinks by hyposmic and normosmic, independently living older persons S. Kremer*, N. Holthuysen, H. Peppelenbos, Wageningen University and Research Centre, The Netherlands Sensory and chemical properties of apple cultivars grown in North-Eastern Europe and their potential for low-alcohol cider production

[P203] R. Kuljärv* ${ }^{1,2}$, M. Holm ${ }^{1,2}$, T. Paalme ${ }^{1,2},{ }^{1}$ Competence Center of Food and Fermentation Technologies, Estonia, ${ }^{2}$ Tallinn University of Technology, Estonia 
[P205] A. Kuznetsova* ${ }^{1}$, P.B. Brockhoff ${ }^{1}$, T. Næs ${ }^{1}$, O. Tomic ${ }^{1},{ }^{1}$ DTU, Denmark, ${ }^{2}$ DTU, Denmark, ${ }^{3}$ Nofima, Norway, ${ }^{4}$ Norwegian Knowledge Centre for the Health Services, Norway

Application of the free sorting method to categorize shampoo fragrances

[P206] F. Laffin*, A. Grelier, A.C. Grzanka, M. Bouzard, F. Pense, A.M. Pense-Lheritier, B. Thuillier, Ecole de Biologie Industrielle, France

Consumer evaluation of commercially produced convenience cheeses using a scaled Image Measurement of Emotion and Texture (IMET) Method

[P207] K.P. Martinez ${ }^{1}$, A.M. Lammert ${ }^{1}$, H. Herrera ${ }^{1}, \mathrm{~K}_{\text {. McGaughey }}{ }^{1}$, H. Ashman ${ }^{1}$, ${ }^{1}$ California Polytechnic State University, USA, ${ }^{2}$ Washington University, USA, ${ }^{3}$ Muse, USA

Do we need an emotional cleanser? An example using experimentally developed low moisture part skim mozzarella with partial $\mathrm{NaCl}$ substitution

[P208] K.P. Martinez ${ }^{1}$, A.M. Lammert ${ }^{* 1}$, H. Herrera ${ }^{2}$, K. McGaughey ${ }^{1}$, M. Arnold ${ }^{1}$, N. Farkye ${ }^{1}$, R. Jimenez-Flores ${ }^{1}$ ${ }^{1}$ California Polytechnic State University, USA, ${ }^{2}$ Washington University, USA

Development of a questionnaire to measure attraction toward sweet, salty and fatty foods in children

[P209] C. Lange $*^{1}$, R. Schoumacker ${ }^{2}$, W. Yuan ${ }^{2}$, C. Chabanet ${ }^{2}$, S. Nicklaus ${ }^{2},{ }^{1}$ CNRS, UMR6265 Centre des Sciences du Goût et de l'Alimentation, France, ${ }^{2}$ INRA, UMR1324 Centre des Sciences du Goût et de l'Alimentation, France

[P210] A review of Irish consumer food studies to generate a profile of the average Irish consumer M. Broderick, A. Bouchier-Hayes, T. Larkin*, Limerick Institute of Technology, Ireland Sensory characterization of marine oils and development of a sensory lexicon and aroma wheel

[P211] W.E. Larssen* ${ }^{1}$, E. Monteleone ${ }^{2}$, M. Hersleth ${ }^{3},{ }^{1}$ Møreforsking, Norway, ${ }^{2}$ University of Florence, Italy, ${ }^{3}$ Nofima, Norway

An assessment of the choice making and purchase intentions among fast food customers according to gender

[P212] A.D. Lassen*, C. Lehmann, E.W. Andersen, J.D. Iversen, A.V. Thorsen, E. Trolle, I. Tetens, G. Gross, Technical University of Denmark, Denmark

[P213] Compliance to oral nutritional supplements in frail elderly: A sense of perceived behavioural control? J.B. Lawlor, Danone Nutricia Research, The Netherlands

[P214] What type of information do people look for when buying fish?

O. Lazo $*^{1,2}$, A. Claret ${ }^{1}$, L. Guerrero ${ }^{1},{ }^{1}$ IRTA, Spain, ${ }^{2}$ CIBA IPN, Mexico

[P215] Paper withdrawn

[P216] Use of non-verbal evaluation in a food tasting context affected by social desirability bias G. Le Goff $*^{1,2}$, J. Delarue ${ }^{1,2}$, P. Gurviez ${ }^{1,2},{ }^{1}$ AgroParisTech, France, ${ }^{2}$ INRA, France, ${ }^{3}$ CNAM, France

[P217] Emotional response to sweeteners in tea

K.A. Leitch*, S.E. Duncan, J. Dunsmore, S. O'Keefe, Virginia Polytechnic Institute and State University, USA Enhancing sensory characteristics, hedonics and expected food intake behaviour through emulsion design

[P218] A.M. Lett ${ }^{*}{ }^{1}$, J.E. Norton ${ }^{1}$, I.T. Norton ${ }^{1}$, M.R. Yeomans ${ }^{2},{ }^{1}$ University of Birmingham, UK, ${ }^{2}$ University of Sussex, UK

[P219] United Kingdom J.L. Li $*^{1}$, L.M. Methven ${ }^{1}$, D.T. Thomson ${ }^{2},{ }^{1}$ University of Reading, UK, ${ }^{2} M M R$ Research Worldwide, UK Sensory characterisation of Solaris white wines from Denmark

[P220] J. Liu* ${ }^{1}$, A. Kuznetsova ${ }^{2}$, W. Bredie ${ }^{1},{ }^{1}$ University of Copenhagen, Denmark, ${ }^{2}$ Technical University of Denmark, Denmark

[P221] cured meat products

L. Lorido*, J. Ventanas, S. Ventanas, University of Extremadura, Spain

Training of a sensory panel in the use of the temporal dominance of sensations (tds) method to the sensory

[P222] description of dry-cured meat products

L. Lorido*, J. Ventanas, S. Ventanas, University of Extremadura, Spain

Global implementation of SQS difference from control methodology to guide product quality

C. Lucak*, J. Santana, DuPont Nutrition \& Health, USA

Improving sensory quality of food product to meet the elderly's preferences: Which winning strategy?

[P224] I. Maître $*^{1,4}$, R. Symoneaux ${ }^{1,4}$, S. Issanchou ${ }^{2,3}$, P. De Facq ${ }^{1,4}$, J. Tavares ${ }^{1,4}$, V. Feyen ${ }^{2,3}$, C. Martin ${ }^{2,3}$, V. Van Wymelbeke ${ }^{5}$, C. Sulmont-Rossé ${ }^{2,3},{ }^{1}$ Groupe ESA, France, ${ }^{2}$ INRA Dijon, France, ${ }^{3}$ Centre des Sciences du Goût et de l'Alimentation, France, ${ }^{4}$ SFR 4207 QUASAV, France, ${ }^{5} \mathrm{CHU}$ Dijon, France

How information about food affects facial expressions - measure by Face Reading Technology D. Majchrzak* ${ }^{1}$, K. Achleitner ${ }^{1}$, B. Aumayr ${ }^{1}$, M. Joechl ${ }^{2}$, L. Danner ${ }^{2}{ }^{2}$, K. Duerrschmid $^{2},{ }^{1}$ University of Vienna, Austria, ${ }^{2}$ University of Natural Resources and Life Sciences (BOKU), Austria, ${ }^{3}$ University of Applied Sciences Wiener Neustadt, Campus Wieselburg, Austria 
[P226] D. Majchrzak* ${ }^{1}$, P. Mitmannsgruber ${ }^{1}, \mathrm{~K}_{\text {. Fronius }}{ }^{2}, \mathrm{~K}-\mathrm{H}$. Wagner ${ }^{1},{ }^{1}$ University of Vienna, Austria, ${ }^{2}$ Claudus BioLebensmittel vom Schlattbauerngut, Austria

[P227] Olfactory perception in blind and visually impaired people: Do blind people develop superior smell ability? D. Majchrzak*, J. Eberhard, University Vienna, Austria

SAM "Success-Mapping": Understanding drivers of market-success based on products' sensory

[P228] characteristics

P. Manfredi*, I. Tronconi, M. Kern, SAM Sensory and Marketing International GmbH, Italy Innovate in cheeses aroma by designing new microbial solutions thanks to a combined approach of

[P229] chromatography and sensory techniques

E. Manoury, DUPONT, France

Temporal dominance of sensations of fresh-cheese pies: A tool to study expected satiety

[P230] J. Marcano $*^{1}$, M.J. Pereira ${ }^{2}$, P. Varela ${ }^{1}$, S. Fiszman ${ }^{1},{ }^{1}$ Instituto de Agroquimica y Tecnologia de Alimentos, Spain, ${ }^{2}$ Universidade de Porto, Portugal

The role of different packages for transportation on persimmon shelf life

[P231] M. Martineli*1, M.J.O. Fonseca ${ }^{2}$, A.G. Soares ${ }^{2}$, C.T.G. Mattos ${ }^{2}$, C.M. Rezende ${ }^{1}$, R. Deliza ${ }^{2},{ }^{1}$ IQ/Federal University of Rio de Janeiro, Brazil, ${ }^{2}$ Embrapa Food Technology, Brazil

[P232] $\begin{aligned} & \text { Influence of caffeine metabolism on coffee consumption and perception } \\ & \text { C. Masi }{ }^{1}, \mathrm{C} \text {. Dinnella }{ }^{1} \text {, J. Prescott }{ }^{2}, \mathrm{M} \text {. Barnabà }{ }^{3}, \mathrm{~L} \text {. Navarini }{ }^{3}, \mathrm{E} \text {. Monteleone }{ }^{1}{ }^{1} \text { University of Florence, Italy, }\end{aligned}$ ${ }^{2}$ TasteMatters Research \& Consulting, Australia, ${ }^{3}$ illycaffè SpA, Italy

The physiology of coffee drinkers

[P233] C. Masi ${ }^{1}$, C. Dinnella ${ }^{1}$, E. Monteleone ${ }^{1}$, J. Prescott ${ }^{2},{ }^{1}$ University of Florence, Italy, ${ }^{2}$ TasteMatters Research \& Consulting, Australia

[P234] Modeling: Application to dark chocolates

M. Masson $*^{1,2}$, P. Lestringant ${ }^{1}$, J. Delarue ${ }^{1,2}$, D. Blumenthal ${ }^{1,2},{ }^{1}$ Agroparistech, France, ${ }^{2}$ INRA, France

An exploration of napping and its reliability as a rapid profiling technique

[P235] N. Mathieu*, Y. Taylor, K. Greenhoff, product perceptions Ltd, UK

[P236] cream

N.S. Matias*, R. Bedani, I.A. Castro, S.M.I. Saad, University of São Paulo, Brazil

[P237] Influence of insulin and milk proteins on sensory acceptability of synbiotic açai ice cream

M.G.M. Costa, G.N. Ooki, N.S. Matias*, R. Bedani, S.M.I. Saad, University of São Paulo, Brazil

[P238] Sensory evaluation of cheese from sardinian dairy sheep production systems at different input levels C. Medoro*, P. Pirino, E. Gatti, M. Magli, P. Duce, E. Vagnoni, S. Predieri, CNR, Italy Three in a row: Screening panelists, products and attributes for a subsequent descriptive analysis using

[P239] napping and ultra flash profiling J. Meier*, C. Schabe, Neubrandenburg University of Applied Sciences, Germany

[P240] Sensitivity and specificity of a sensory quality control method: The case of boar taint L. Meier-Dinkel*, J. Gertheiss, D. Mörlein, Georg August University of Goettingen, Germany

[P241] The case of boar taint; how sensory science provides knowledge for decision making in the industry L. Meinert*, M.D. Aaslyng, Danish Meat Research Institute, Denmark

Global exploration of consumer psychographics for the phytonutrient supplement product category

[P242] C.L. Kuesten ${ }^{1}$, J. Bi ${ }^{2}$, H.L. Meiselman* ${ }^{3},{ }^{1}$ Amway, USA, ${ }^{2}$ Sensometric Research and Service, USA, ${ }^{3}$ Herb Meiselman Training and Consulting Services, USA

[P243] Characterisation of cooked ham using the method of Temporal Dominance of Sensations (TDS) J. Messadène*, B. Guggenbühl, Agroscope, Switzerland

[P244] Correlation between shear forces and tenderness of beef meat perceived by Swiss consumers J. Messadène*, P-A. Dufey, Agroscope, Switzerland

Sweet perception and sucrose rejection thresholds of sweet likers and dislikers

[P245] L. Methven $*^{1}$, C. Xiao ${ }^{1}$, J. Prescott ${ }^{2},{ }^{1}$ University of Reading, UK, ${ }^{2}$ Taste Matters Research \& Consulting, Australia

Product manipulation of fruit drinks sweetened with stevia and how it influences affective consumer responses and buying intention

[P246] L. Mielby* ${ }^{1}$, S. Jensen ${ }^{1}$, H. Kildegaard ${ }^{2}$, A. Kuznetsova $^{3}$, N. Eggers ${ }^{1}$, B.V. Andersen ${ }^{3}$, P.B. Brockhoff ${ }^{3}$, D.V. Byrne ${ }^{1},{ }^{1}$ Aarhus University, Denmark, ${ }^{2}$ Arla Strategic Innovation Centre, Denmark, ${ }^{3}$ Technical University of Denmark, Denmark 
Effect of means of context evocation and type of evoked context on consumers response towards fruit drinks

[P247] L.H. Mielby* ${ }^{1}$, S. Jensen ${ }^{1}$, H. Kildegaard ${ }^{2}$, A. Kuznetsova ${ }^{3}$, N. Eggers ${ }^{1}$, B.V. Andersen ${ }^{4}$, P.B. Brockhoff ${ }^{3}$, D.V. Byrne ${ }^{1},{ }^{1}$ Aarhus University, Denmark, ${ }^{2}$ Arla Strategic Innovation Centre, Denmark, ${ }^{3}$ DTU, Denmark, ${ }^{4}$ National Food Institute, DTU, Denmark

What to measure in exposure studies? Liking, Wanting and Intake does not tell the same story in a bread study

[P248] L.H. Mielby*1 ${ }^{1}$, H. Kildegaard ${ }^{2}$, I. Amorim ${ }^{3}, 4$, S. Jensen ${ }^{1}$, P.B. Brockhoff ${ }^{4}$, D.V. Byrne ${ }^{1},{ }^{1}$ Aarhus University, Denmark, ${ }^{2}$ Arla Strategic Innovation Centre, Denmark, ${ }^{3}$ UFLA, Brazil, ${ }^{4}$ DTU, Denmark

Combining temporal dominance of sensations and discrete time intensity to characterize the dynamic

[P249] profile of food

C. Dinnella ${ }^{1}$, C. Masi ${ }^{1}$, G.P. Zoboli ${ }^{2}$, E. Monteleone ${ }^{* 1},{ }^{1}$ University of Florence, Italy, ${ }^{2}$ Adacta International, Italy Assessing the emotional and sensory effects of a beauty care for women

[P250] M. Mortillaro* ${ }^{1}$, S. Gagnaire ${ }^{2}, \mathrm{~K}_{\text {. Vié }}{ }^{2}, \mathrm{D}$. Sander ${ }^{1},{ }^{1}$ University of Geneva, Switzerland, ${ }^{2}$ Laboratoires Clarins Inc., France

Comparison of different methods to evaluate agreement between panellists in profile analysis

[P251] R. Nachtsheim**1, A. Gere ${ }^{2}$, L. Sipos ${ }^{2}$, R. Ludi ${ }^{3}$, Z. Kókai ${ }^{2}$, E. Schlich ${ }^{1}$, ${ }^{1}$ University Gießen, Germany, ${ }^{2}$ Corvinus University Budapest, Hungary, ${ }^{3}$ Walter Rau Lebensmittelwerke GmbH, Germany

[P252] R. Nachtsheim ${ }^{* 1}$, R. Ludi ${ }^{2}$, E. Schlich ${ }^{1},{ }^{1}$ University Gießen, Germany, ${ }^{2}$ Walter Rau Lebensmittelwerke GmbH, Germany

[P253] Relationship between parent-child dyads in seafood consumption, attitudes and preferences B.T. Nystrand*, K.L. Fjørtoft, Møreforsking AS, Norway

Using Temporal Dominance of Sensations for understanding subtle sensory differences between milk puddings produced in factory and in laboratory

[P254] M. Okaue ${ }^{*},{ }^{1}$ Y. Yamada ${ }^{1}$, K. Ihara $^{1}$, R. Koizumi ${ }^{1}$, K. Watanabe ${ }^{1}$, M. Sumi ${ }^{1}$, P. Schlich ${ }^{2},{ }^{1}$ Morinaga Milk Industry Co., Ltd., Japan, ${ }^{2}$ INRA, France

Effects of color and aroma on predicting the type of tea before drinking

[P255] S. Okuda* ${ }^{1}$, A. Takemura ${ }^{2}, \mathrm{~K}$. Okajima $^{3},{ }^{1}$ Doshisha Women's College of Liberal Arts, Japan, ${ }^{2}$ Setsunan University, Japan, ${ }^{3}$ Yokohama National University, Japan

Designing meals for elderly with eating difficulties: A cooperative approach

[P256] V. Olsson* ${ }^{1}$, M. Nyberg ${ }^{1}$, Z. Pajalic ${ }^{2}$, G. Örtman ${ }^{1}$, A. Westergren ${ }^{1}$, A. Blücher ${ }^{2}$, H. Andersson ${ }^{2}$, K. Wendin $^{3,4}$, ${ }^{1}$ Kristianstad University, Sweden, ${ }^{2}$ Linnaeus University, Sweden, ${ }^{3}$ SP Technical Research Institute of Sweden, Sweden, ${ }^{4}$ University of Copenhagen, Denmark

Effect of chitosan based edible coatings enriched with antimicrobials on the aromatic profile of summer

[P257] truffles (Tuber aestivum)

M.E. Venturini, P. Marco, D. Blanco, R. Oria*, University of Zaragoza, Spain

Retailer's and consumers' perceptions about the Zero Residue stone fruit: Trends and barriers in the European market

[P258] E. Campo ${ }^{1}$, M. Brun ${ }^{1}$, E. Sarneel ${ }^{1}$, M.E. Venturini ${ }^{1}$, R. Oria* ${ }^{1},{ }^{1}$ University of Zaragoza, Spain, ${ }^{2}$ Transfer Latin Business Consultancy, Spain

[P259] Use of a conditioning procedure to induce positive emotional associations with novel foods K.E. Osdoba*, Z.M. Vickers, University of Minnesota, USA

[P260] $\begin{aligned} & \text { Sensory and physiochemical comparison of trat } \\ & \text { and ageing using a moisture permeable bag }\end{aligned}$ M.G. O'Sullivan* ${ }^{1}$, D.V. Byrne ${ }^{2},{ }^{1}$ University College Cork, Ireland, ${ }^{2}$ Aarhus University, Denmark Efficient sensory methods for the identification and characterization of umami compounds S. Paetz*, S. Mundt, J.P. Ley, M. Kassing, M. Backes, Symrise AG, Germany Quantitative Descriptive Analysis of cashew beverage with different substitutes of sucrose added with

[P262] Psyllium Prebiotic A.C. Correa, J.A. Paixao*, E.A. Esmerino, H.M.A. Bolini, University of Campinas, Brazil

[P263] Consumers' perspectives on food in tubes in Sweden: An exploratory study K.M.B. Paredes, Lund University, Sweden Having choice: Does it influence pleasantness and food intake?

[P264] O. Parizel ${ }^{*^{1,3}}$, J. Delarue ${ }^{2}$, A. Marsset-Baglieri ${ }^{1}$, C. Sulmont-Rossé ${ }^{3}$, G. Fromentin ${ }^{1},{ }^{1}$ AgroParisTech-INRA, France, ${ }^{2}$ AgroParisTech-INRA-CNAM, France, ${ }^{3}$ INRA, France 
Effect of extracting reducing sugars on the sensory quality of potato chips

[P266] C. Illanez ${ }^{2}$, A. Bunger ${ }^{2}$, S. Mariotti ${ }^{1}$, F. Pedreschi* ${ }^{1},{ }^{1}$ Pontificia Universidad Catolica de Chile, Chile, ${ }^{2}$ Universidad de Chile, Chile

Can consumers cope with rapid profiling methods? An overview and comparison offlash profiling, napping

[P267] and polarized sensory positioning

S. Peleteiro Costa*, J.S. Arden, A. Goupil de Bouillé, Leatherhead Food Research, UK

[P268]

Analysis of consumer preferences in Madrid (Spain) to select the 'perfect' extra virgin olive oil

M.A. Perez*, C. Mena, IMIDRA. Comunidad de Madrid, Spain

[P269] Measuring beverages drinkability

C. Perrin* $*^{1}$, J. Cortes ${ }^{1}$, C. Godefroy ${ }^{2}$, C. Adam ${ }^{2},{ }^{1}$ Givaudan, Switzerland, ${ }^{2}$ Givaudan, France

Sensory and instrumental approaches to evaluate the quality of cookies enriched with medicinal herbs

[P270] M. Pestoric*, O. Šimurina, D. Jambrec, B. Filipcev, A. Mišan, M. Belovic, N. Nedeljkovic, Institute of Food Technology, Serbia

The sensory quality of differently treated tomato varieties after storage

[P271] M. Pestoric*, M. Belovic, Z. Kevresan, J. Mastilovic, M. Pojic, A. Novakovic, T. Radusin, E. Janic Hajnal, B. Cvetkovic, N. Ilic, Institute of Food Technology, Serbia

[P272] Innovative food pairing of cheese and distillates

S. Petignat-Keller*, E. Beutler, R. Badertscher, C. Freiburghaus, Agroscope, Switzerland

[P273] Combining sensory profiles using "Flash PSP" methodology: Advantages and limitations

C. Petit* ${ }^{1}$, J. Delarue ${ }^{2}$, E. Teillet ${ }^{3},{ }^{1}$ Puratos N.V., Belgium, ${ }^{2}$ AgroParisTech, France, ${ }^{3}$ SensoStat, France

Young consumers' attitudes and behaviour towards sustainable and healthy eating

[P274] Z. Pieniak* ${ }^{1}$, S. Zakowska-Biemans ${ }^{2}$, E. Kostyra ${ }^{2},{ }^{1}$ Consumer and Sensory Research Institute, Poland, ${ }^{2}$ Warsaw University of Life Science, Poland

Evaluation of the sensory profile and consumer acceptance of instant soup reduced in sodium and added with salt replacers, flavours, herbs and spices

[P275] G.C.M.C. Bannwart ${ }^{1}$, G. Vidal ${ }^{2}$, M.E.M. Pinto e Silva* ${ }^{1}$, M. Jacon ${ }^{3}$, L. Aburad ${ }^{1},{ }^{1}$ USP, $_{\text {Brazil, }}{ }^{2}$ UNICAMP, Brazil, ${ }^{3}$ UNESP, Brazil

Use of grape skin flour for novel food development: Sensory characterization and acceptability of soft cheeses

[P276] M. Piochi ${ }^{1}$, L. Torri ${ }^{1}$, R. Marchiani ${ }^{2}$, G. Zeppa ${ }^{2}$, E. Monteleone ${ }^{3}$, ${ }^{1}$ University of Gastronomic Sciences, Italy ${ }^{2}$ Università degli Studi di Torino, Italy, ${ }^{3}$ University of Florence, Italy

Yum versus Yuck! Relationships between consumers' traits and their explicit and implicit motivations toward appealing and disgusting foods

[P277] B. Piqueras-Fiszman $*^{1}$, A.A. Kraus ${ }^{2}$, C. Spence ${ }^{1},{ }^{1}$ Wageningen University, The Netherlands, ${ }^{2}$ Aarhus University, Denmark

Optimization of a verbal measure of emotions elicited by fragrances; comparison between CATA (Check-AllThat-Apply) and a 5-point scale

[P278] C. Porcherot* ${ }^{1}$, D. Valentin ${ }^{2}$, C. Ducret ${ }^{1}$, O. Grand ${ }^{2}$, C. Melis ${ }^{2}$, H. Vergnaud ${ }^{2}$, N. Gaudreau ${ }^{1}$, I. Cayeux $^{1}$, ${ }^{1}$ FIRMENICH SA, Switzerland, ${ }^{2}$ AGROSUP, France

Country of origin and product/usage features: The contribution of cognitive economics

[P279] S. Porretta ${ }^{1}$, H. Moskowitz ${ }^{1}$, S. Rappaport ${ }^{1}$, B. Batalvi ${ }^{1},{ }^{1}$ Experimental Station for the Food Preserving Industry, Italy, ${ }^{2}$ Moskowitz Jacobs, Inc, USA, ${ }^{3}$ Stephen D. Rappaport Consulting LLC, USA, ${ }^{4}$ SB\&B Marketing Research, Canada

[P280] Consumer preference and perception of macadamia nuts

Y. Khatri ${ }^{1}$, S. Wei ${ }^{2}$, W. Posri $*^{1},{ }^{1}$ Harper Adams University, UK, ${ }^{2}$ Chienkuo Technology University, Taiwan

Recognition thresholds and liking of sensations derived from capsaicin and one-penten-3-one among chilli

[P281] users

N. Toontom ${ }^{1}$, M. Meenune ${ }^{1}$, W. Posri* ${ }^{2}$, ${ }^{1}$ Prince of Songkla University, Thailand, ${ }^{2}$ Harper Adams University, UK Influence of flavour enhancement on food liking and consumption in elderly depending on their cognitive

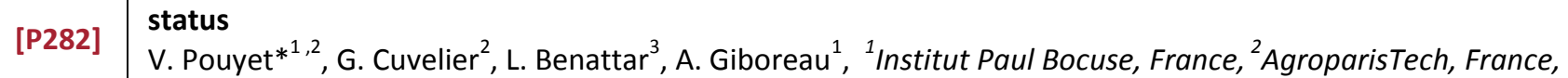
${ }^{3}$ ORPEA, France

Senior consumer involvement in developing satisfactory pasta sauces with healthy ingredients

[P283] S. Predieri* ${ }^{1}$, G. Sotis ${ }^{2}$, P. Rodinò ${ }^{2}$, E. Gatti ${ }^{1}$, M. Magli ${ }^{1}$, F. Rossi ${ }^{1}$, C. Medoro ${ }^{1}$, M. Cianciabella ${ }^{1}$, R. Volpe $^{2}$, ${ }^{1}$ IBIMET-BIOAGROFOOD, Italy, ${ }^{2}$ SPP-CNR, Italy

CATA question for understanding consumer perception on persimmon milkshakes rich in carotenoids M. Hernández-Carrión ${ }^{1}$, P. Varela ${ }^{2,3}$, I. Hernando ${ }^{1}$, S. Fiszman $*^{2}$, A. Quiles ${ }^{1},{ }^{1}$ Universitat Politècnica de València (UPV), Spain, ${ }^{2}$ Instituto de Agroquímica y Tecnología de Alimentos (IATA-CSIC), Spain, ${ }^{3}$ Nofima AS, Norway 
Identification of drivers of liking for medical food products

J. Rason*, E. Booijink, M. Vader, J.B. Lawlor, Nutricia Research, The Netherlands

[P286] P. Rébénaque ${ }^{* 1}, \mathrm{~A}$. Rawyler ${ }^{1}, \mathrm{M}-\mathrm{O}$. Boldi ${ }^{2}, \mathrm{P}$. Deneulin ${ }^{1},{ }^{1}$ Changins- University for Viticulture and Oenology, Switzerland, ${ }^{2}$ University of Geneva-GSEM, Switzerland

Survey about Brazilians black consumers' necessities regarding makeups

[P287] F.B. Ribas*, M.C. Marcolini, J.T. Bueno, E.L. Rocha, M. Lorencini, V.M. Di Mambro, Cencoderma Instituição de Pesquisa, Brazil [P288] $\begin{aligned} & \text { Investigating consumers' perceptions about biotechnology on food production using a semantic differential } \\ & \text { scale }\end{aligned}$

T.G. Ribeiro*, J.H. Behrens, University of Campinas, Brazil

[P289] fat potato purees

[P289] C. Talens ${ }^{1}$, M. García-Quiroga ${ }^{1}$, M. Castro-Giraldez ${ }^{2}$, P.J. Fito ${ }^{2}$, Y. Rios ${ }^{* 1},{ }^{1}$ Azti-Tecnalia, Spain, ${ }^{2}$ Universidad Politécnica de Valencia, Spain

Senior consumer preference: Max diff methodology as a measure of the relative importance of the

[P290] attributes of the product at the time of purchase

Y. Ríos*, I. Gartzia, M. García, AZTI-Tecnalia, Spain

[P291] Comparison of food neophobia between adults and adolescents of a spanish speaking population A. Roascio*, L. Raggio, A. Gámbaro, Universidad de la República, Uruguay

Influence of information on the label of aromatized olive oil in traditional and emerging consumer markets

[P292] A. Roascio* ${ }^{1}$, A. Gámbaro ${ }^{1}$, C. Stinco ${ }^{2}$, A. Melendez ${ }^{2},{ }^{1}$ Universidad de la República, Uruguay, ${ }^{2}$ Universidad de Sevilla, Spain

[P293] Determination of detection and recognition threshold of the five basic-tastes in passion fruit juice I. Rocha*, H. Bolini, University of Campinas, Brazil

Preparation methods and ingredients influence gastronomical outcome of hollandaise sauce

[P294] G.H. Rognså ${ }^{1,2}$, M. Hersleth ${ }^{3}$, M. Sivertsvik ${ }^{3}$, J. Risbo ${ }^{2},{ }^{1}$ The Culinary Institute of Norway, Norway, ${ }^{2}$ University of Copenhagen, Denmark, ${ }^{3}$ Nofima, Norway

[P295] The liking test, bringing new dimensions to dog and cat food palatability measurement

A. Becques, J. Roguès*, C. Niceron, Diana Pet Food, France

Assessment of preconscious sucrose perception using EEG

[P296] C.A. Rotvel ${ }^{* 1,2}$, S. Møller ${ }^{1}$, R.R. Nielsen ${ }^{1}$, O.N. Larsen ${ }^{3}$, P. Kidmose ${ }^{2},{ }^{1}$ DuPont Nutrition Biosciences, Brabrand, Denmark, ${ }^{2}$ Aarhus University, Denmark, ${ }^{3}$ University of Southern Denmark, Denmark

Understanding intrinsic quality assessment of red wines by experts

[P297] M-P. Sáenz-Navajas* ${ }^{1,2}$, J-M. Avizcuri ${ }^{3}$, J-F. Echavarri ${ }^{4}$, V. Ferreira ${ }^{1}$, P. Fernádez-Zurbano ${ }^{3}$, D. Valentin $^{2}$, ${ }^{1}$ Universidad de Zaragoza, Spain, ${ }^{2}$ Centre du Goût et de l'Alimentation, France, ${ }^{3}$ Instituto de Ciencias de Vid y el Vino, Spain, ${ }^{4}$ Universidad de La Rioja, Spain

Comparison of holistic or analytic approaches to characterize perceptions of high level alcohol beverages

[P298] during consumption

A. Saint-Eve ${ }^{*^{1,2}}$, S. Jourdren ${ }^{2,1}$, G. Fiches ${ }^{3,2}$, I. Déléris ${ }^{2,1}$, P. Brunerie ${ }^{3}$, I. Souchon ${ }^{2,1},{ }^{1}$ AgroParisTech, France, ${ }^{2}$ INRA, France, ${ }^{3}$ Pernod Ricard, France

[P299] Temporal consideration of the relationships between texture perception and bolus formation in cheeses A. Saint-Eve ${ }^{*^{1,2}}$, M. Panouillé ${ }^{1,2}$, I. Déléris ${ }^{2,1}$, I. Souchon ${ }^{2,1},{ }^{1}$ AgroParisTech, France, ${ }^{2}$ INRA, France Ability of adults to identify pure taste modalities is roller-coastering

[P300] M.A. Sandell*, O. Laaksonen, A. Knaapila, H. Terho, S. Mattila, P. Ojansivu, U. Hoppu, University of Turku, Finland

[P301] Sensory and health related characteristics of rye bread in Sweden P. Sandvik*, I. Marklinder, M. Nydahl, I. Kihlberg, Uppsala University, Sweden Liking for fat is associated with socio-demographic, psychological, lifestyle and health characteristics

[P302] A. Lampuré ${ }^{1}$, A. Deglaire ${ }^{2,3}$, P. Schlich ${ }^{2}$, K. Castetbon $^{1}$, S. Péneau ${ }^{1}$, S. Hercberg ${ }^{1}$, C. Méjean ${ }^{1},{ }^{1}$ Université Paris 13, France, ${ }^{2}$ Université de Bourgogne, France, ${ }^{3}$ Inra Science et Technologie du Lait et de l'CEuf, France Baby Gourmet - The impact of feeding deep frozen complementary food products, compared to canned baby foods, on the liking of new foods at the age of about 9 months

[P303] I.V. Schmidt* ${ }^{1}$, A. Hilbig ${ }^{1}$, M. Kersting ${ }^{1}$, J. Kunert ${ }^{2},{ }^{1}$ Research Institute of Child Nutrition, Germany, ${ }^{2}$ TU Dortmund University, Germany

[P304] Electronic noses and their possible applications in the food industry - Status quo and prospects M. Mueller von Blumencron, B. Schneider-Haeder*, J. Oehlenschlaeger, DLG e.V., Germany 
Acceptance of milk obtained from a traditional, genetically modified or cloned animal and satisfaction with food-related life in South America

[P306] B. Schnettler ${ }^{1}{ }^{1}$, C. Velasquez ${ }^{1}$, G. Crisóstomo ${ }^{1}$, H. Miranda ${ }^{1}$, L. Orellana ${ }^{1}$, J. Sepúlveda ${ }^{1}$, K.G. Grunert $^{2}$, ${ }^{1}$ Universidad de La Frontera, Chile, ${ }^{2}$ Aarhus University, Denmark

Dietary restriction, food consumption habits and wellbeing in students from state universities in Chile

[P307] B. Schnettler ${ }^{*}{ }^{1}$, H. Miranda ${ }^{1}$, L. Orellana ${ }^{1}$, J. Sepúlveda ${ }^{1}$, M. Denegri ${ }^{1}$, S. Etchebarne ${ }^{2}$, M. Mora ${ }^{2}$, G. Lobos $^{3}$, K.G. Grunert ${ }^{4},{ }^{1}$ Universidad de La Frontera, Chile, ${ }^{2}$ Universidad de Chile, Chile, ${ }^{3}$ Universidad de Talca, Chile, ${ }^{4}$ Aarhus University, Denmark

How does information about the benefits of fruit consumption influence consumer preferences in South America?

[P308] B. Schnettler*1, H. Miranda ${ }^{1}$, L. Orellana ${ }^{1}$, J. Sepúlveda ${ }^{1}$, M. Mora ${ }^{2}$, G. Lobos ${ }^{3}$, C. Adasme ${ }^{4}$, K.G. Grunert $^{5}$, ${ }^{1}$ Universidad de La Frontera, Chile, ${ }^{2}$ Universidad de Chile, Chile, ${ }^{3}$ Universidad de Talca, Chile, ${ }^{4}$ Universidad Católica del Maule, Chile, ${ }^{5}$ Aarhus University, Denmark

[P309] sweetener

J.J. Schouteten*, S. De Pelsmaeker, V. Courtois, X. Gellynck, Ghent University, Belgium

An ambient scent guides likeability ratings

[P310] P.F.R. Hehn ${ }^{1}$, M. Strack ${ }^{1}$, B. Schubert ${ }^{*}{ }^{2},{ }^{1}$ isi GmbH \& Co. KG, Germany, ${ }^{2}$ Harz University of Applied Sciences, Germany

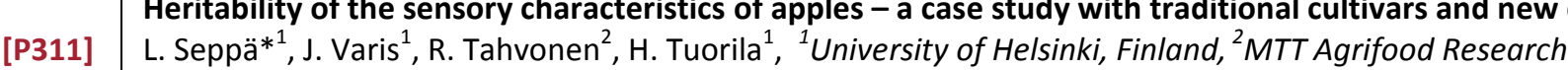
Finland, Finland

[P312] different ice cream flavors-innovation in traditional oriental sweets M. Serhan ${ }^{*}{ }^{1}$, R. Hallab ${ }^{1},{ }^{1}$ University of Balamand, Lebanon, ${ }^{2}$ Rafaat Hallab \& Sons, Lebanon Emotional and functional conceptualisations for beer, wine and non-alcoholic beer consumption in The Netherlands and in Portugal

[P313] A.P. Silva ${ }^{1,4}$, G. Jager $^{1}$, R. van Bommel ${ }^{1}$, H. van Zyl ${ }^{2}$, H-P. Voss ${ }^{3}$, M. Pintado ${ }^{4}$, T. Hogg ${ }^{4}$, K. De Graaf $^{1}$, ${ }^{1}$ Wageningen University, The Netherlands, ${ }^{2}$ Heineken, The Netherlands, ${ }^{3}$ Voss ID, The Netherlands,

${ }^{4}$ Universidade Católica Portuguesa, Portugal

Consumers' cognition of freshness in vegetables and fruits

[P314] F. Sinesio*, A. Saba, M. Peparaio, E. Moneta, F. Paoletti, Agricultural Research Council - Centre of Food and Nutrition (CRA-NUT), Italy

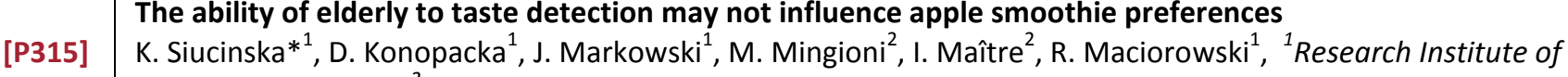
Horticulture, Poland, ${ }^{2}$ UPSP GRAPPE, Groupe ESA, France

A comparison of the random error structure in different serving designs for sensory analysis

[P316] H.K. Sivertsen $*^{1}$, D.M. Barrett ${ }^{1}$, T. Næs ${ }^{1},{ }^{1}$ UCDavis, USA, ${ }^{2}$ Nofima the Food Research Institute, Norway, ${ }^{3}$ University of Copenhagen, Denmark

\section{How sensory and branding affect liking and emotions in delicate laundry detergents}

[P317] S. Spinelli $*^{1}$, B. Piccoli ${ }^{2}$, G.P. Zoboli ${ }^{2}$, E. Monteleone ${ }^{3},{ }^{1}$ SemioSensory - Research \& Consulting, Italy, ${ }^{2}$ Adacta International S.p.A., Italy, ${ }^{3}$ University of Florence, Italy

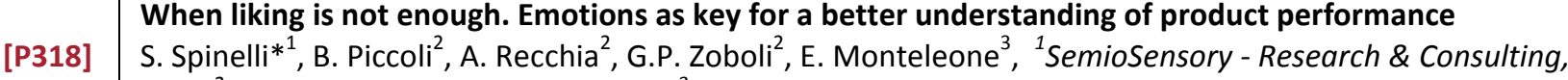
Italy, ${ }^{2}$ Adacta International S.p.A., Italy, ${ }^{3}$ University of Florence, Italy

Evidence for different patterns of chemosensory alterations in the elderly population: Impact of age versus dependency

[P319] C. Sulmont-Rossé ${ }^{1}{ }^{1}$, M. Amand ${ }^{2}$, S. Issanchou ${ }^{1}$, I. Maître ${ }^{3},{ }^{1}$ INRA, France, ${ }^{2}$ ONIRIS, France, ${ }^{3}$ UPSP GRAPPE, France

Proximal versus distal contextual factors: Which impact on meal pleasure and food intake in the elderly living in a nursing home?

[P320] C. Sulmont-Rossé $*^{1}$, C. Divert ${ }^{1}$, R. Laghmaoui ${ }^{2}$, C. Crema ${ }^{2}$, V. Van Wymelbeke ${ }^{2},{ }^{1}$ INRA, France, ${ }^{2}$ Unité de Recherche Service de Médecine Interne Gériatrie, Dijon, France

Consumer liking of ready-to-eat meals enriched with omega-3

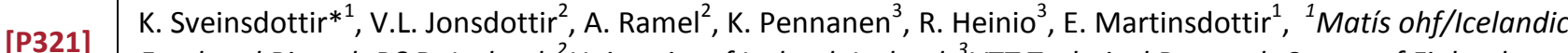
Food and Biotech R\&D, Iceland, ${ }^{2}$ University of Iceland, Iceland, ${ }^{3}$ VTT Technical Research Centre of Finland, Finland

[P322] Variability of wine bottles in sensory tastings

R. Symoneaux*, C. Patron, Groupe ESA - UR GRAPPE, France 
Assessment of sensory quality of pasta with fermented husk of green lentil seeds and selected extracts of spices

K. Szymandera-Buszka*, A. Jedrusek-Golinska, M. Gumienna, M. Lasik, K. Waszkowiak, Poznan University of Life Sciences, Poland

Exploring the psychology and product factors underlying the acceptance and rejection of edible insects amongst Thai and Dutch consumers

[P324] H.S.G. Tan ${ }^{1}{ }^{1}$, P. Tinchan ${ }^{2}$, L.P.A. Steenbekkers ${ }^{1,3}$, M.A. Stieger ${ }^{1}$, A.R.H. Fischer ${ }^{1},{ }^{1}$ Wageningen University, The $^{2}$ Netherlands, ${ }^{2}$ Kasetsart University Chalermphrakiat Sakon Nakhon Province Campus, Thailand, ${ }^{3}$ Wageningen UR Food and Biobased Research, The Netherlands

[P325] Italian cold-pressed hazelnut oils: Conjoint analysis of sensory quality vs volatile profile F. Tesini*, R. Palagano, E. Valli, S. Barbieri, A. Bendini, T. Gallina Toschi, University of Bologna, Italy Case study of inter-store navigation methods and interactive consumer tracking software A.J. Spink, B. van Mill, B. Loke, L.P.J.J. Noldus, H. Theuws*, Noldus Information Technology, The Netherlands Alternating temporal dominance of sensations and liking scales during the intake of a full portion of an oral nutritional supplement

[P327] A. Thomas ${ }^{1}{ }^{1}$, A. Van der Stelt ${ }^{2}$, J.B. Lawlor ${ }^{2}$, P. Schlich ${ }^{1},{ }^{1}$ INRA/CNRS/Université de Bourgogne, France, ${ }^{2}$ Nutricia Advanced Medical Nutrition, France

[P328] $\begin{aligned} & \text { Application of conceptual profiling to Gl antacid tablet and chewable product category } \\ & \mathrm{H} . \mathrm{Xing}^{1}, \mathrm{~B} \text {. Weinstein }\end{aligned}$ Worldwide, USA

[P329] analysis (DA) in preference mapping of mint chewing gum K. Tiitinen ${ }^{* 1}$, A. Lammers ${ }^{1}$, S. Corneau ${ }^{2},{ }^{1}$ Symrise, Germany, ${ }^{2}$ Symrise, France

\section{Designed scent: Tools and methods for olfactory analysis in automotive field}

[P330] B. Lerma ${ }^{1}$, L. Torri* ${ }^{2}$, E. Buiatti ${ }^{1}$, E. Pagin ${ }^{3}$, D. Costamagna ${ }^{3},{ }^{1}$ Politecnico di Torino, Italy, ${ }^{2}$ University of Gastronomic Sciences, Italy, ${ }^{3}$ Graduate designers at the Politecnico di Torino, Italy

Use of a multi-method approach for the training and selection of professional tasters: The case study of coffee

[P331] L. Torri ${ }^{1}$, M. Piochi ${ }^{1}$, G. Pellegrino ${ }^{2}$, A. Vanni ${ }^{2},{ }^{1}$ University of Gastronomic Sciences, Italy, ${ }^{2}$ Luigi Lavazza SpA, Italy

[P332] Choice of Greek style yogurt is affected by its sensory properties and the eating patterns of consumers R. Hajj Ahmad, A. Chalak, A. Olabi, I. Toufeili*, American University of Beirut, Lebanon

Detection of boar taint at slaughter: Quantification of olfactory acuity and how it is related to assessor

[P333] performance

J. Trautmann*, J. Gertheiss, M. Wicke, D. Mörlein, Department of Animal Sciences, Germany

The effect of sugar concentration on the perception of flavour from model orange juice drinks

[P334] P. Tsitlakidou* ${ }^{1}$, O. Buysschaert ${ }^{2}$, H. Haest ${ }^{2}$, R. Wiguna ${ }^{1}$, L. Methven ${ }^{1}$, J.S. Elmore ${ }^{1},{ }^{1}$ University of Reading, UK, ${ }^{2}$ S.A. Coca-Cola Services N.V., Belgium

Comparison of Canadian men and women salient beliefs regarding milk and cheese consumption: $\mathrm{A}$

[P335] qualitative study exploring differences in cognitive vs. hedonic perceptions

M. Turcotte*, G. Painchaud Guérard, M-J. Lacroix, S. Desroches, P. Paquin, F. Couture, V. Provencher, Laval University, Canada

[P336] Consumer food preferences and ethnocentrism: A Norwegian investigation M. Vab $\varnothing^{* 1,2}$, K.V. Hansen ${ }^{1}$, H. Kraggerud ${ }^{1},{ }^{1}$ University of Stavanger, Norway, ${ }^{2}$ TINE BA R\&D, Norway

Coupling both a sensory and an emotional study to evaluate the consumers' rejection behavior: Study case in rejection of medicines

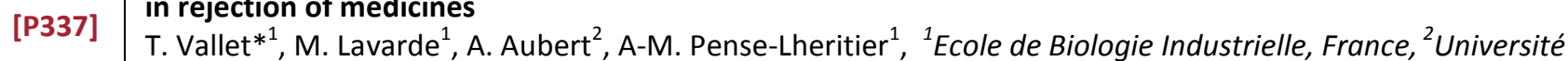
de Tours, France

[P338] Development of a reliable and valid "action standard grid" for Medical Nutrition R\&D A.J. van der Stelt ${ }^{*}{ }^{1}$, A. Hasted ${ }^{2}$, J.B. Lawlor ${ }^{1},{ }^{1}$ Danone Nutricia Research, The Netherlands, ${ }^{2}$ Qi Statistics, UK Understanding heterogeneity among elderly consumers in the functional food market: A segmentation

[P339] study based on perceived carrier appropriateness L.D.T. van der Zanden*, E. van Kleef, R.A. de Wijk, H.C.M. van Trijp, Wageningen University, The Netherlands Application of mobile eye-tracking for better understanding a projective mapping task

[P340] P. Varela* ${ }^{1,2}$, L. Antúnez ${ }^{3}$, R. Silva Cadena ${ }^{3}$, A. Gimenez ${ }^{3}$, G. Ares ${ }^{3},{ }^{1}$ Nofima AS, Norway, ${ }^{2}$ Instituto de Agroquímica y Tecnología de Alimentos (CSIC), Spain, ${ }^{3}$ Universidad de la República, Uruguay

[P341] and partial PSP with a descriptive step

P. Varela*, K. Svartebekk Myhrer, T. Næs, M. Hersleth, Nofima Ås, Norway 
[P342] A. Mazzaglia ${ }^{1}$, C.M. Lanza ${ }^{1}$, G. Tripodi ${ }^{2}$, C. Condurso ${ }^{2}$, A. Verzera $*^{2},{ }^{1}$ University of Catania, Italy, ${ }^{2}$ University of Messina, Italy

Sensory analysis for quality assessment of mini-watermelon fruits grafted on different rootstocks

[P343] A. Mazzaglia ${ }^{1}$, C.M. Lanza ${ }^{1}$, E. Sperlinga ${ }^{1}$, C. Restuccia ${ }^{1}$, G. Tripodi ${ }^{2}$, G. Dima $^{2}$, A. Verzera* ${ }^{2},{ }^{1}$ University of Catania, Italy, ${ }^{2}$ Department of Chemical Science, Italy

[P344] Segmentation of consumers : New approaches for discarding irrelevant information M. Chen ${ }^{1}$, E. Vigneau* ${ }^{1}$, B. Navez ${ }^{2}$, V. Cottet ${ }^{2},{ }^{1}$ Oniris, France, ${ }^{2}$ CTIFL, France

[P345] Cephalic phase response to a palatable or unpalatable food

I. Mennella, P. Vitaglione*, University of Naples, Italy

[P346] Salivary enzymatic activity and zinc concentration in subjects with different body mass index I. Mennella, P. Vitaglione*, University of Naples, Italy

How does task design influence consumers' gazing behavior in an eye-tracking test? An empirical study on food images

[P347] T.M.H. Vu*1, ${ }^{* 1}$, V.P. Tu ${ }^{1}$, K. Duerrschmid ${ }^{2},{ }^{1}$ Hanoi University of Science and Technology, Vietnam, ${ }^{2}$ University of Natural Resources and Life Sciences BOKU, Austria

[P348] technology to light-induced off-flavours in milk A.M. Walsh*, B. Bortz, H. Potts, S.E. Duncan, Virginia Polytechnic Institute and State University, USA Sensory evaluation of food products fortified with potato juice

[P349] K. Waszkowiak*, A. Jedrusek-Golinska, K. Szymandera-Buszka, P. Kowalczewski, M. Piatek, M. KrzywdzinskaBartkowiak, Poznan University of Life Sciences, Poland

How physiological signals influence consumer perception of attractive presenters in advertisement

[P350] F.T. Wehrle ${ }^{*^{1,2}}$, R. Vanheems ${ }^{2},{ }^{1}$ ICD International Business School, France, ${ }^{2}$ University Paris1 Pantheon Sorbonne, France

Designed energy smoothie for elderly

U. Nilsson ${ }^{1}$, G. Hagstrom ${ }^{2}$, M. Uggla ${ }^{3}$, M.E. Olsson ${ }^{3}$, M. Biorklund ${ }^{4}$, P. Arinder ${ }^{5}$, K. Wendin* ${ }^{6,7}{ }^{1}{ }^{1}$ irgo

[P351] Consulting, Sweden, ${ }^{2}$ Lyssna Ltd, Sweden, ${ }^{3}$ Swedish Agricultural University, Sweden, ${ }^{4}$ Skåne Food Innovation Network, Sweden, ${ }^{5}$ SIK-The Swedish Institute for Food and Biotechnology, Sweden, ${ }^{6}$ Kristianstad University, Sweden, ${ }^{7}$ SP Technical Research Institute of Sweden, Sweden, ${ }^{8}$ University of Copenhagen, Denmark

[P352] fabric V.J. Whelan*, V. Cotte, British American Tobacco, UK

Odour profiles of used incontinence products

[P353] H. Widén*1 ${ }^{1}$ S. Alenljung ${ }^{2}$, U. Forsgren-Brusk ${ }^{2}, \mathrm{G}$. Hall ${ }^{1},{ }^{1}$ SIK - the Swedish Institute for Food and Biotechnology, Sweden, ${ }^{2}$ SCA Hygiene Products $A B$, Sweden

In consumer test involving sensory questions, should the liking score be asked first or last? An element of [P354] response through a case study...

T. Worch $*^{1}$, A. Goupil de Bouillé ${ }^{1},{ }^{1}$ QI Statistics, UK, ${ }^{2}$ Leatherhead, UK

PrefMFA: A new vision to perform preference mapping

T. Worch, QI Statistics, UK

[P356] Effect of PROP and thermal taster status on perception of temperature

Q. Yang ${ }^{* 1}$, T. Hollowood ${ }^{2}$, J. Hort ${ }^{1},{ }^{1}$ University of Nottingham, UK, ${ }^{2}$ Sensory Dimensions, UK

Is individual variation in taste perception link to personal trait behaviours?

[P357] Q. Yang ${ }^{* 1}$, T. Hollowood ${ }^{2}$, J. Hort ${ }^{1},{ }^{1}$ University of Nottingham, UK, ${ }^{2}$ Sensory Dimensions, UK

[P358] The scale of sound

N. Zacharov*, T.H. Pedersen, J. Ramsgaard, DELTA SenseLab, Denmark

[P359] Impact of innovation on consumers' liking and willingness to pay for pork cooked sausages S. Zakowska-Biemans*, M. Sajdakowska, K. Gutkowska, Warsaw University of Life Sciences, Poland Shaking salt perceptions: The use of table salt with reduced-salt products

[P360] E.H. Zandstra*1 ${ }^{1}$, H.L. De Kock ${ }^{2}$, N. Sayed ${ }^{3}$, E. Wentzel-Viljoen ${ }^{4},{ }^{1}$ Unilever R\&D Vlaardingen, The Netherlands, ${ }^{2}$ University of Pretoria, South Africa, ${ }^{3}$ Unilever South Africa, South Africa, ${ }^{4}$ North West University, South Africa Organization and activities of the working group protected designation of origin of the european sensory

[P361] $\begin{array}{ll}\text { Science society } \\ \text { M. Zannoni*1 }\end{array}$ ${ }^{2}$ Universitad del Pais Vasco / Euskal Herriko Unibertsitatea, Spain

Effectiveness of the sensory fast method CATA in chocolate Quality control validated by intensity ratings and compared with DHS-GC-MS

[P362] S. Zhang ${ }^{* 1}$, S. Waehrens ${ }^{1}$, D. Byrne ${ }^{1,2}$, M. Petersen ${ }^{1},{ }^{1}$ University of Copenhagen, Denmark, ${ }^{2}$ Aarhus University, Denmark 
Exploring influences of CD36 SNPs and different fatty acids on fat perception in subjects with varying BMI X. Zhou*, Y. Shen, L. Methven, O. Kennedy, University of Reading, UK

[P364] Napping procedure with incomplete designs of experiment: How to analyse the data? U. Zigon, Frutarom Etol d.o.o., Slovenia

[P365] The emotional landscape of vanilla across the world

[P365] D. Paredes ${ }^{1}$, V. Zuccoli**2, ${ }^{1}$ Takasago International Corporation, USA, ${ }^{2}$ Takasago Europe GmbH, Germany

Does increasing statistical power in Sorting and Napping by replicates also lead to a learning effect?

[P366] M. Grønbeck*1 ${ }^{1}$, H. Hopfer ${ }^{2}$, H. Heymann ${ }^{2},{ }^{1}$ University of Copenhagen, Denmark, ${ }^{2}$ University of California, Davis, USA

Swiss wine and cheese pairings, a happy wedding!

[P367] V. Jaggi ${ }^{1}$, P. Piccinali*2 ${ }^{2}$ P. Deneulin ${ }^{1},{ }^{1}$ Changins University for Viticulture and Oenology, Switzerland, ${ }^{2}$ Agroscope, Switzerland

\section{Oral Poster Programme}

The oral posters will be displayed throughout the conference

\begin{tabular}{|c|c|}
\hline $\begin{array}{l}\text { Poster } \\
\text { Number }\end{array}$ & Poster Title \\
\hline [OP01] & $\begin{array}{l}\text { Children's sensitivity to basic tastes and their corresponding acceptance and intake of representative } \\
\text { lemonades } \\
\text { M. Hersleth }{ }^{1}{ }^{1} \text {, V. Dånmark Vatn }{ }^{2} \text {, I. Berget }{ }^{1} \text {, N. Lien }{ }^{2} \text {, V. Lengard Almli }{ }^{1},{ }^{1} \text { Nofima AS, Norway, }{ }^{2} \text { University of } \\
\text { Oslo, Norway }\end{array}$ \\
\hline [OP02] & $\begin{array}{l}\text { Engaging elementary students to improve consumption of healthful foods in schools } \\
\text { A. Snelling }{ }^{1}, \mathrm{C} \text {. Newman }{ }^{2}, \mathrm{~J} \text {. Guthrie }{ }^{2} \text {, L. Mancino }{ }^{2},{ }^{1} \text { American University, USA, }{ }^{2} \text { USDA-ERS, USA }\end{array}$ \\
\hline [OP03] & $\begin{array}{l}\text { Food enjoyment in children - Effects of a learning program } \\
\text { K.S. Myhrer*, V.A. Almli, M. Hersleth, Nofima AS, Norway }\end{array}$ \\
\hline [OP04] & $\begin{array}{l}\text { A thousand ways to say 'delicious!' } \\
\text { W. Ariyasriwatana*, L.M. Quiroga, University of Hawaii, USA }\end{array}$ \\
\hline [OP05] & $\begin{array}{l}\text { An international comparison of eating habits usinga mobile application capturing consumers own } \\
\text { photographs and comments along their day } \\
\text { A. Brugerolle, C. Hugol-Gential, A. Giboreau*, Institut Paul Bocuse, France }\end{array}$ \\
\hline [OP06] & $\begin{array}{l}\text { Evaluating consumers' willingness to buy environmentally friendly wines: A store experiment } \\
\text { E. Ginon }{ }^{1}, \mathrm{P} . \text { Bazoche }{ }^{2}, \mathrm{~L} . \mathrm{H} \text {. Esteves dos Santos Laboissière }{ }^{3,4}, \mathrm{~J} . \text { Brouard }^{1}, \mathrm{~S} \text {. Issanchou } *^{3},{ }^{1} \text { Burgundy School } \\
\text { of Business, France, }{ }^{2} \text { INRA, UR1303, France, }{ }^{3} \text { INRA, UMR1324 CSGA, France, }{ }^{4} \text { Universidade Federal de Minas } \\
\text { Gerais, Brazil }\end{array}$ \\
\hline [OP07] & $\begin{array}{l}\text { "Tasty sounds": When the sound symbolism of the product's name influences consumers' overall } \\
\text { perception and liking } \\
\text { S. Favalli* }{ }^{1,2}, \text { T. Skov }{ }^{1}, \text { C. Spence }{ }^{2}, \text { D.V. Byrne }{ }^{3},{ }^{1} \text { Copenhagen University, Denmark, }{ }^{2} \text { University of Oxford, UK, } \\
{ }^{3} \text { Aarhus University, Denmark }\end{array}$ \\
\hline [OP08] & $\begin{array}{l}\text { Chinese consumers' use of food nutrition label and its determinants } \\
\text { R. Liu }{ }^{1,2}, \text { C. Hoefkens }{ }^{1}, \text { W. Verbeke }{ }^{1},{ }^{1} \text { Ghent University, Belgium, }{ }^{2} \text { China Women's University, China }\end{array}$ \\
\hline
\end{tabular}

